\title{
Sedimentary record from the Canada Basin, Arctic Ocean: implications for late to middle Pleistocene glacial history
}

\author{
Linsen Dong ${ }^{1,2}$, Yanguang Liu ${ }^{1,2}$, Xuefa Shi ${ }^{1,2}$, Leonid Polyak ${ }^{3}$, Yuanhui Huang ${ }^{1,2}$, Xisheng Fang ${ }^{1}$, Jianxing Liu ${ }^{1,2}$, \\ Jianjun Zou ${ }^{1,2}$, Kunshan Wang ${ }^{1,2}$, Fuqiang Sun ${ }^{1}$, and Xuchen Wang ${ }^{4}$ \\ ${ }^{1}$ Key Laboratory of Marine Sedimentology and Environmental Geology, First Institute of Oceanography, State Oceanic \\ Administration, Qingdao, 266061, China \\ ${ }^{2}$ Laboratory for Marine Geology, Qingdao National Laboratory for Marine Science and Technology, Qingdao, 266061, China \\ ${ }^{3}$ Byrd Polar and Climate Research Center, The Ohio State University, Columbus, 43210, USA \\ ${ }^{4}$ Key Laboratory of Marine Chemistry Theory and Technology, Ocean University of China, Qingdao, 266100, China
}

Correspondence to: Xuefa Shi (xfshi@fio.org.cn)

Received: 27 December 2016 - Discussion started: 16 January 2017

Accepted: 24 April 2017 - Published: 23 May 2017

\begin{abstract}
Sediment core ARC4-BN05 collected from the Canada Basin, Arctic Ocean, covers the late to middle Quaternary (Marine Isotope Stage - MIS - 1-15, ca. 0.5-0.6 Ma) as estimated by correlation to earlier proposed Arctic Ocean stratigraphies and $\mathrm{AMS}^{14} \mathrm{C}$ dating of the youngest sediments. Detailed examination of clay and bulk mineralogy along with grain size, content of $\mathrm{Ca}$ and $\mathrm{Mn}$, and planktic foraminiferal numbers in core ARC4-BN05 provides important new information about sedimentary environments and provenance. We use increased contents of coarse debris as an indicator of glacier collapse events at the margins of the western Arctic Ocean, and identify the provenance of these events from mineralogical composition. Notably, peaks of dolomite debris, including large dropstones, track the Laurentide Ice Sheet (LIS) discharge events to the Arctic Ocean. Major LIS inputs occurred during the stratigraphic intervals estimated as MIS 3, intra-MIS 5 and 7 events, MIS 8, and MIS 10. Inputs from the East Siberian Ice Sheet (ESIS) are inferred from peaks of smectite, kaolinite, and chlorite associated with coarse sediment. Major ESIS sedimentary events occurred in the intervals estimated as MIS 4, MIS 6 and MIS 12. Differences in LIS vs. ESIS inputs can be explained by ice-sheet configurations at different sea levels, sediment delivery mechanisms (iceberg rafting, suspension plumes, and debris flows), and surface circulation. A longterm change in the pattern of sediment inputs, with an apparent step change near the estimated MIS 7-8 boundary (ca. $0.25 \mathrm{Ma}$ ), presumably indicates an overall glacial expan-
\end{abstract}

sion at the western Arctic margins, especially in North America.

\section{Introduction}

The advances and decays of continental ice sheets play a significant role in the alteration of global climatic system, such as changing atmospheric circulations, creating largearea albedo anomalies and regulating the global sea level fluctuations (Clark et al., 1990). Reconstruction of the history of ice sheets is therefore important not only for a better understanding of feedbacks of the future climate change and its impact on regional climates but also for getting insights into the mechanisms of abrupt climate change.

Studies of Pleistocene glaciations around the Arctic Ocean dealt mostly with the late Quaternary history of the Eurasian Ice Sheet during Marine Isotope Stages (MIS) 1-6 (e.g., Svendsen et al.,2004; Larsen et al., 2006) or the Laurentide Ice Sheet (LIS) with a special attention to the Last Glacial Maximum (LGM) (e.g., Dyke et al., 2002; England et al., 2009). In addition to terrestrial data, studies of sediment cores from the Arctic Ocean are critical for comprehending the history of glacial advances and retreats (e.g., Polyak et al., 2004, 2009; Spielhagen et al., 2004; Stein et al., 2012; Kaparulina et al., 2016). However, the long-term history of circum-Arctic glaciations is still poorly understood, especially with respect to the western Arctic including the North America and East Siberia. A major impact of the North 


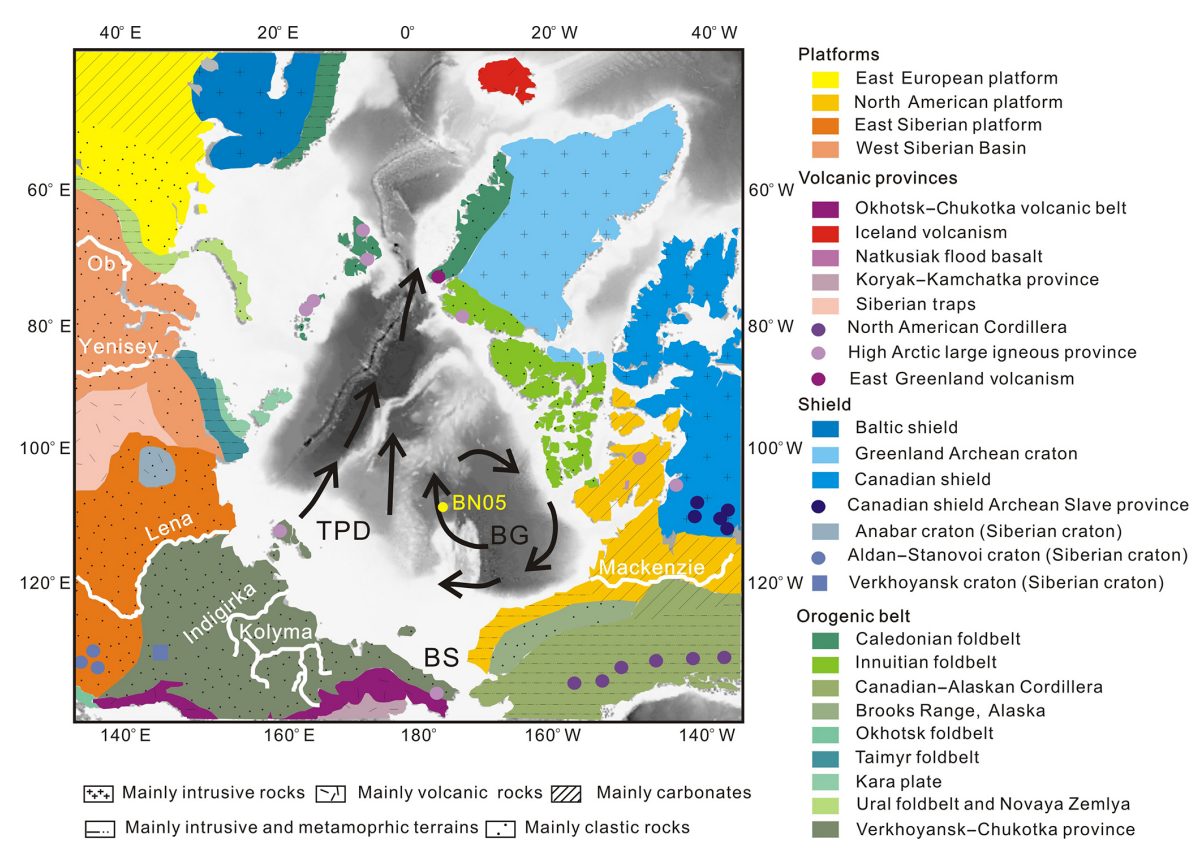

Figure 1. Background map showing the location of core ARC4-BN05,the main Arctic rivers and the two major surface current systems: Beaufort Gyre (BG), Transpolar Drift (TPD) and Bering Strait (BS). Schematic geological map shows the distribution and prevailing lithology of the main terrains adjacent to the Arctic Ocean (Fagel et al., 2014).

American ice sheets on circulation and depositional environments in the Arctic Ocean is indicated by various marine and terrestrial data (e.g., Phillips and Grantz, 2001; Stokes et al., 2005), whereas the East Siberian Ice Sheet (ESIS) remained largely hypothetical until recently. While terrestrial data are limited and remain to be better investigated (Grosswald, 1989; Basilyan et al., 2010; Ivanova, 2012), seafloor mapping data now provide ample evidence for the existence of considerable ice masses on the East Siberian margin (Niessen et al., 2013; Dove et al., 2014; Jakobsson et al., 2014, 2016), but the timing and extent of these glaciations is virtually unknown. Marine sedimentary records from the Arctic Ocean adjacent to the East Siberian margin could add valuable information to this intriguing paleoglaciological problem.

In this paper, we present a multiproxy study of glacialinterglacial changes during the late to middle Pleistocene based on sediment core ARC4-BN05 from the Canada Basin north of the Chukchi Plateau and east of the Mendeleev Ridge (Fig. 1). This location can be affected by the two main Arctic Ocean circulation systems, the Beaufort Gyre and the Transpolar Drift, which carry sea ice, icebergs, and sediment discharge from North America and Siberia, respectively. As this circulation along with sedimentary environments and sources varied greatly during the Pleistocene climate cycles, resulting variations in sediment delivery and deposition make for a valuable paleoclimatic record for the western Arctic. Biogenic proxies (such as foraminifers) have uneven and overall limited distribution in Arctic Ocean sediments, while the terrigenous component provides a more consistent mate- rial for paleoceanographic studies (e.g. Stein, 2008; Polyak et al., 2009). As sediments in the Arctic Ocean are primarily transported by sea ice and/or icebergs during glacial events, sediment composition yields important information not only on the provenance and transport pathways but also on the attendant glacial and paleoclimatic history (e.g. Spielhagen et al., 1997; Vogt et al., 2001; Knies et al., 2001). By using clay and bulk mineralogy, along with grain size and the content of major elements $\mathrm{Ca}$ and $\mathrm{Mn}$, we reconstruct depositional environments and sediment provenance to provide clues to the history of western Arctic ice sheets and their interaction with the Arctic Ocean.

\section{Regional background}

The Arctic Ocean is surrounded by land masses composed of an assortment of lithologies and situated in a variety of climatic, tectonic, and physiographic settings. Figure 1 depicts a schematic geological map showing the main terrains and associated lithologies (Fagel et al., 2014). The West Siberian Basin and East Siberian platform of the Eurasian continent are mainly composed of terrigenous sediment (Fagel et al., 2014). The Siberian (Putorana) traps constitute one of the largest flood basalts in the world (Sharma et al., 1992). The western Okhotsk-Chukotsk volcanic belt contains acidic to intermediate rocks, whereas intermediate to basic rocks are more characteristic of the eastern side (Viscosi-Shirley et al., 2003). The Kara Plate and the Taymyr foldbelt, as well as the 
Ural and Novaya Zemlya foldbelt, are mainly composed of intrusive and metamorphic rocks (Fagel et al., 2014).

The geology of outcropping terraines of Alaska mainly includes Canadian-Alaskan Cordillera, Brooks Range, and part of the North American platform containing mostly intrusive, metamorphic, and some clastic rocks (Fagel et al., 2014). The outcrops of the Canadian Arctic Archipelago are mainly composed of carbonate and clastic rocks (Phillips and Grantz, 2001; Fagel et al., 2014), whereas intrusive and clastic rocks are mostly characteristic for Greenland (Fagel et al., 2014).

Dissolved and suspended matter is transported to the Arctic Ocean by voluminous rivers, with the Lena and Mackenzie rivers being the largest on the Siberian and North American side, respectively, both directly affecting the western Arctic Ocean. The transported material is further distributed across the Arctic Ocean in water and/or ice by currents. The two main surface, wind-driven circulation systems are the clockwise Beaufort Gyre (BG) in the western Arctic and the Transpolar Drift (TPD), which carries water and ice from the Siberian margin to the Norwegian-Greenland Sea (e.g., Rudels, 2009). The strength and trajectories of these current systems may vary depending on changes in atmospheric pressure fields known as the Arctic Oscillation (Rigor et al., 2002).

Sedimentation in the Arctic Ocean is strongly controlled by sea ice that acts as sediment carrier but can also suppress sediment deposition under thick and persistent ice cover (Darby et al., 2006; Polyak et al., 2009). During glacial/deglacial events, multiple icebergs discharged into the Arctic Ocean from the termini of marine-based ice sheets and strongly affected sediment dispersal and deposition (e.g., Spielhagen et al., 2004; Polyak et al., 2009). Fine-grained sediments can also be transported by subsurface and deepwater currents, such as the Atlantic water (Winkler et al., 2002), but their role in the overall Arctic Ocean sedimentation is not well understood.

\section{Materials and methods}

Gravity core ARC4-BN05 (referred to hereafter as BN05) was collected from the Canada Basin in the vicinity of the Mendeleev Ridge $\left(80^{\circ} 29.04^{\prime} \mathrm{N}, 161^{\circ} 27.90^{\prime} \mathrm{W}\right.$; $3156 \mathrm{~m}$ water depth) (Figs. 1 and 2) on the fourth Chinese National Arctic Research Expedition (CHINARE-IV) in 2009. The BN05 site was chosen in close proximity to earlier investigated cores FL224 and PS72/392-5 (Clark et al., 1980; Stein et al., 2010a) to enable robust correlation with the established stratigraphies. A total of 119 samples were taken at $2 \mathrm{~cm}$ intervals over the $238 \mathrm{~cm}$ BN05 length, and kept frozen until analyzed.

For age constraint within the radiocarbon range, accelerator mass spectrometry ${ }^{14} \mathrm{C}$ dating was performed on 1000-1200 tests of planktic foraminifers (Neogloboquadrina

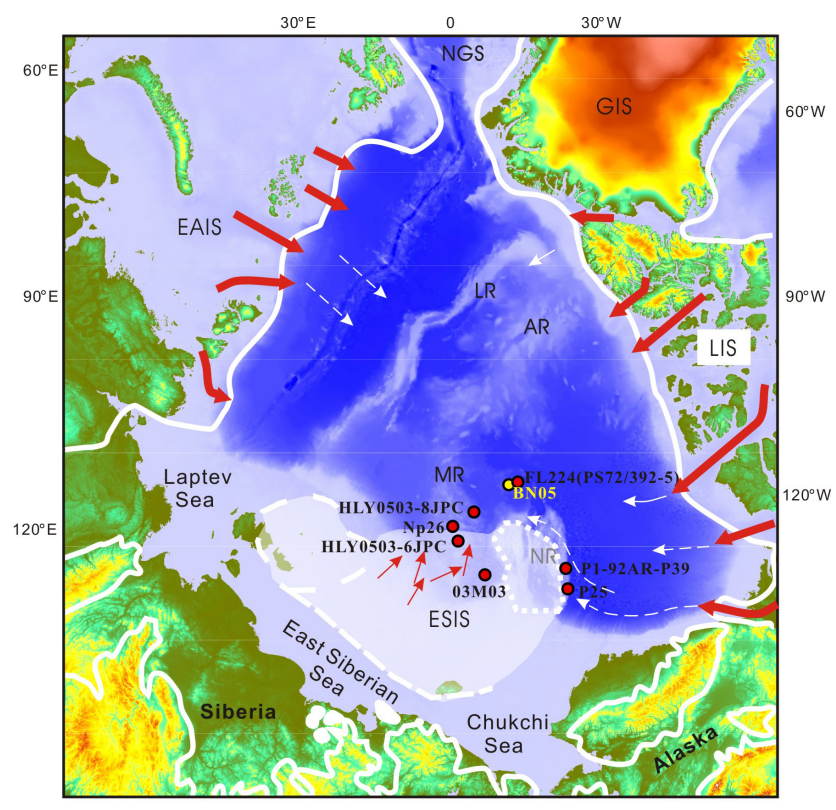

Figure 2. Index map showing the location of core ARC4-BN05 (yellow circle) and other cores from previous studies mentioned in this paper (red circles). LR, MR, AR, and NR are Lomonosov, Mendeleev, Alpha, and Northwind ridges, respectively; NGS is Norwegian-Greenland Sea. White lines show maximal Pleistocene limits reconstructed for Greenland, Laurentide, Eurasian, and East Siberian ice sheets (GIS, LIS, EAIS and ESIS; England et al., 2009; Svendsen et al., 2004; Niessen et al., 2013). Proposed flow lines for grounded ice sheets and ice shelves (red and white arrows, respectively) are after Niessen et al. (2013).

pachyderma sin., $>63 \mu \mathrm{m}$ ) from core depths at 4-6, 8-10, 18-20 and 22-24 cm, using the NOSAMS facilities at Woods Hole Oceanographic Institution.

For grain-size analysis, $\sim 2 \mathrm{~g}$ sediment samples were successively treated with $15 \mathrm{~mL}$ of $15 \% \mathrm{H}_{2} \mathrm{O}_{2}, 5 \mathrm{~mL}$ of $3 \mathrm{~mol} \mathrm{~L}^{-1} \mathrm{HCl}$, and $20 \mathrm{~mL}$ of $1 \mathrm{~mol} \mathrm{~L}^{-1} \mathrm{Na}_{2} \mathrm{CO}_{3}$ for removing organic matter, biogenic carbonates, and biogenic silica, respectively. Grain-size measurements in the range of 0.02 to $2000 \mu \mathrm{m}$ were performed on a Malvern Mastersize laser particle sizer (Mastersizer 2000) at the First Institute of Oceanography, SOA, China.

Coarse sediment $>63 \mu \mathrm{m}$ was sieved from $\sim 10-15 \mathrm{~g} \mathrm{sam}-$ ples and counted under the microscope for foraminiferal and mineral grain numbers; planktonic foraminiferal amounts were expressed as percent of the total grain numbers (at least 300 grains per sample counted).

Concentrations of major elements, such as $\mathrm{Ca}$ and $\mathrm{Mn}$, were determined on point samples by ICP-OES (iCAP6300) at the First Institute of Oceanography, SOA, China, following the standard procedures. For a more detailed downcore distribution, relative elemental abundances were obtained at $1 \mathrm{~cm}$ resolution using the Itrax XRF core scanner at the Polar Research Institute of China, set at $20 \mathrm{~s}$ count times, $10 \mathrm{kV}$ X-ray voltage and $20 \mathrm{~mA} \mathrm{X}$-ray current. A good match of the ICP- 


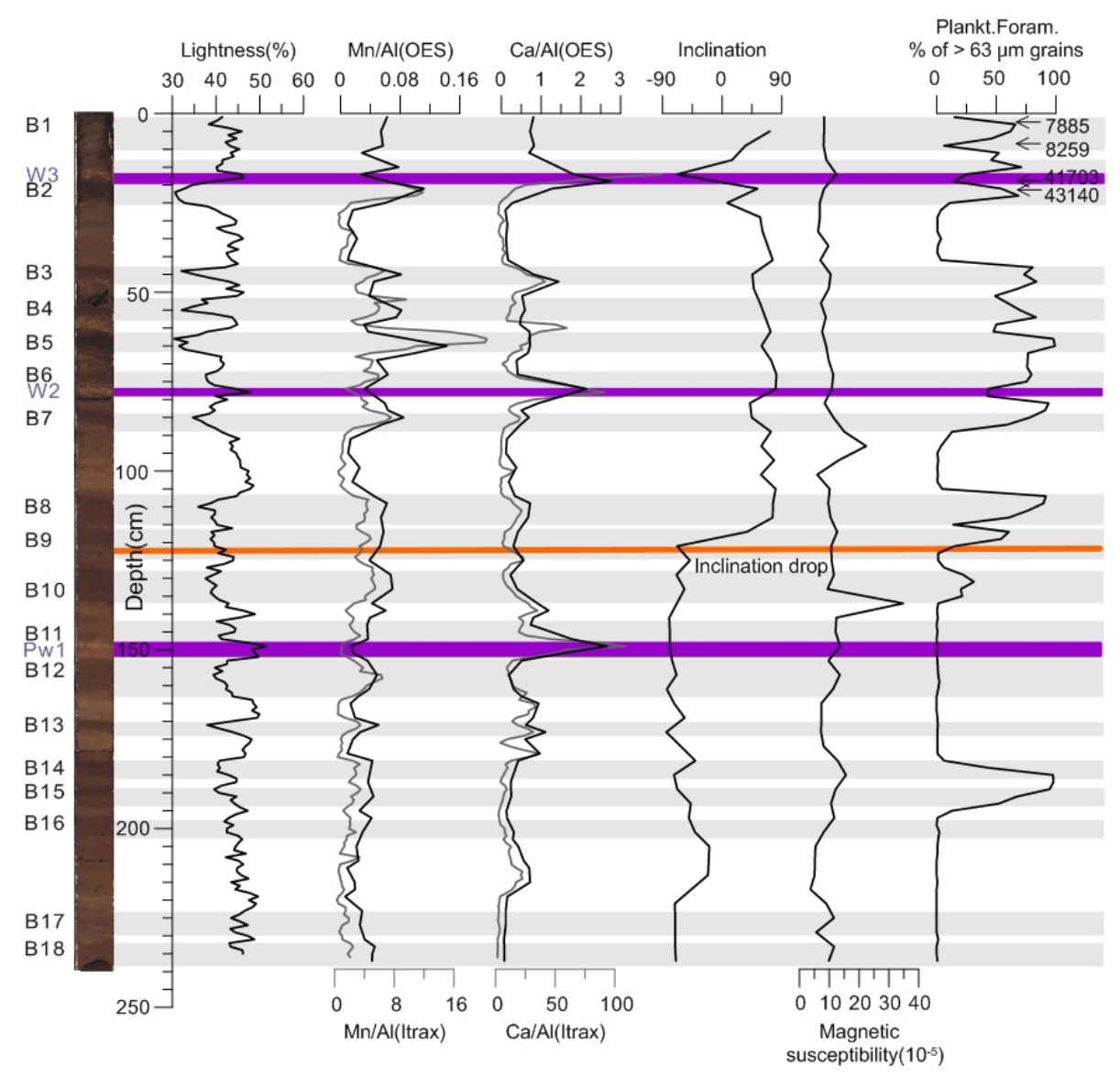

Figure 3. Lithostratigraphy and major proxies in core BN05: core photograph with brown layer indices, lightness, Ca and Mn content (bulk $\mathrm{XRF}$ - gray line, ICP-OES - black line), paleomagnetic inclination, magnetic susceptibility, planktic foraminiferal abundance, and $\mathrm{AMS}{ }^{14} \mathrm{C}$ datings. Predominantly dark-brown intervals B1-B18 are highlighted in gray; high-Ca, pink-white layers are marked by purple lines. The main inclination drop is marked by the orange line. See Table $\mathrm{S} 1$ for data used.

OES and Itrax XRF data (Fig. 3) verifies the consistency of results. To account for the dilution effects on the background sedimentation, such as by coarse debris and biogenic processes, element contents were normalized to $\mathrm{Al}$ (e.g., März et al., 2011).

Color reflectance was measured using a hand-held Minolta CM-2002 spectrophotometer at $1 \mathrm{~cm}$ intervals. Only the grayscale lightness index $\left(L^{*}\right)$ is used in this paper.

A total of sixty $2 \mathrm{~cm}$ thick samples were collected at $4 \mathrm{~cm}$ intervals for paleomagnetic measurements performed at the Paleomagnetism and Geochronology Laboratory of the Institute of Geology and Geophysics, Chinese Academy of Science. Magnetic susceptibility was measured using the KLY-4s Kappabridge instrument. Subsequently, stepwise alternating-field (AF) demagnetization of natural remanent magnetization (NRM) was conducted using the 2-G Enterprises model $760-\mathrm{R}$ cryogenic magnetometer (2G760) installed in a magnetically shielded $(<300 \mathrm{nT})$ space. AF demagnetization steps of 5-10 $\mathrm{mT}$ were used up to a maximum $\mathrm{AF}$ of $100 \mathrm{mT}$.
For bulk sediment mineralogy $\sim 5 \mathrm{~g}$ samples were dried, pulverized, passed through a $63 \mu \mathrm{m}$ sieve, and loaded into aluminum holders. Samples were X-rayed from 5 to $65^{\circ} 2 \theta$ with $\mathrm{Cu}$ K-alpha radiation $(40 \mathrm{kV}, 100 \mathrm{~mA})$ using a step size of $0.02^{\circ} 2 \theta$ and a counting time of $2 \mathrm{~s}$ per step on a $\mathrm{D} / \mathrm{max}-$ 2500 diffractometer equipped with a graphite monochromator with $1^{\circ}$ slits in the laboratory of the First Institute of Oceanography, SOA, China. Prior to the analysis, the instrument was blank-corrected and all samples were measured under the same conditions. Peak areas were estimated from X-ray diffraction (XRD) traces using Jade 6.0 software, and semi-quantitative estimates of bulk mineral percentages were calculated following Cook et al. (1975) (Table 1).

Samples for clay minerals determination $(\sim 5 \mathrm{~g})$ were first treated with $\mathrm{H}_{2} \mathrm{O}_{2}(10 \%)$ and $\mathrm{HCl}\left(1 \mathrm{~mol} \mathrm{~L}^{-1}\right)$ to oxidize the organic matter and remove biogenic carbonates, respectively. Clay fractions $(<2 \mu \mathrm{m})$ were obtained by the Atterberg settling tubes method according to Stoke's law. Each sample was transferred to two slides by wet smearing. Samples were then air-dried prior to XRD analysis. One sample slide was 
Table 1. Minerals actively sought in diffraction data analysis.

\begin{tabular}{lccr}
\hline Mineral & $\begin{array}{c}\text { Window }\left(^{\circ} 2 \theta,\right. \\
\text { CuK } \alpha \text { radiation) }\end{array}$ & $\begin{array}{c}\text { Range of } \\
\text { D-spacing (A) }\end{array}$ & $\begin{array}{r}\text { Intensity } \\
\text { factor* }\end{array}$ \\
\hline Amphibole & $10.30-10.70$ & $8.59-8.27$ & 2.5 \\
Augite & $29.70-30.00$ & $3.00-2.98$ & 5 \\
Calcite & $29.25-29.60$ & $3.04-3.01$ & 1.65 \\
Chlorite & $18.50-19.10$ & $4.79-4.64$ & 4.95 \\
Dolomite & $30.80-31.15$ & $2.90-2.87$ & 1.53 \\
K-feldspar & $27.35-27.79$ & $3.26-3.21$ & 4.3 \\
Quartz & $26.45-26.95$ & $3.37-3.31$ & 1 \\
\hline
\end{tabular}

* The intensity factors are determined in $1: 1$ mixtures with quartz by obtaining the ratio of the diagnostic peak intensity of each mineral with that of quartz, which is assigned a value of 1.00 . The detection limit in weight percent of the minerals in a siliceous or calcareous matrix can be obtained by multiplying the intensity factor by 0.12 (Cook et al., 1975).

air dried at $60^{\circ} \mathrm{C}$ for $2 \mathrm{~h}$ and analyzed. The second sample was solvated with ethylene glycol in an underpressured desiccator for at least $24 \mathrm{~h}$ at $60^{\circ} \mathrm{C}$. Every ethylene-glycol solvated sample was measured twice: the first scanning was done from 3 to $30^{\circ} 2 \theta$ with a step size of $0.02^{\circ}$, and the second scanning from 24 to $26^{\circ} 2 \theta$ with a $0.01^{\circ}$ step. The latter was run as a slow scan to distinguish the $3.54 / 3.58 \AA$ kaolinite/chlorite double peak. Clay minerals were also identified by XRD using a D/max-2500 diffractometer with $\mathrm{CuK} \alpha$ radiation $(40 \mathrm{kV}$ and $100 \mathrm{~mA})$ in the laboratory of the First Institute of Oceanography, SOA, China. Peak areas representing the clay mineral groups were estimated from glycolated XRD traces using the $17 \AA$ smectite, $10 \AA$ illite, and $7 \AA$ chlorite plus kaolinite peaks. Chlorite (004) was identified at $3.54 \AA$ and kaolinite (002) at $3.58 \AA$ (Biscaye, 1964), respectively. Semi-quantitative estimates of clay mineral percentages were calculated by means of Biscaye's (1965) factors.

To enhance the identification of potential contributions from various sediment sources, and thus the interpretation of downcore proxy distributions, principal component analysis (PCA) was performed in MATLAB (MathWorks, 2014). To account for proxies potentially indicative of sediment provenance and depositional processes and environments, PCA included all analyzed mineralogical proxies along with main grain-size groups (clay, silt, fine to medium sand (63$250 \mu \mathrm{m}$ ), and coarser grains), $\mathrm{Ca}$ and $\mathrm{Mn}$ concentrations, and foraminiferal numbers (Table S1 in the Supplement). A combined use of various sedimentological and geochemical data gives informative results in PCA application to paleoclimatic research, including studies of Arctic marine sediments (Pelto, 2014; Simon et al., 2014). The choice of variables for PCA performance was tested by Pearson correlation coefficients (Table S3).
Table 2. $\mathrm{AMS}^{14} \mathrm{C}$ datings in core BN05.

\begin{tabular}{lrrrr}
\hline $\begin{array}{l}\text { Sample } \\
\text { no. }\end{array}$ & $\begin{array}{r}\text { Depth } \\
(\mathrm{cm})\end{array}$ & $\begin{array}{r}\mathrm{AMS}{ }^{14} \mathrm{C} \\
\text { age } \\
\left({ }^{14} \mathrm{C} \text { yr BP }\right)\end{array}$ & $\begin{array}{r}\text { Calibrated } \\
\text { age median } \\
(\text { cal yr BP })\end{array}$ & $\begin{array}{r}2 \sigma \text { range } \\
(\text { cal yr BP })\end{array}$ \\
\hline 112767 & $4-6$ & $7810 \pm 35$ & 7885 & $7797-7958$ \\
112768 & $8-10$ & $8180 \pm 35$ & 8259 & $8171-8340$ \\
112769 & $18-20$ & $38600 \pm 300$ & 41703 & $41202-42165$ \\
115944 & $22-24$ & $40800 \pm 410$ & 43140 & $42522-43901$ \\
\hline
\end{tabular}

\section{Results}

\subsection{General stratigraphy}

As common for sediment cores from the Arctic Ocean (e.g., Jakobsson et al., 2000; Polyak et al., 2004, 2009; Spielhagen et al., 2004; Stein et al., 2010a, b), core ARC4-BN05 displays distinct cycles in sediment color and composition expressed in interlamination of dark-brownish and lightercolored grayish muds (silty clays, clay silts and sandy silt), with coarser dropstones occurring in several layers. The color cyclicity is approximated by changes in sediment lightness that largely mirrors the content of Mn (Fig. 3), consistent with other studies from the Arctic Ocean (e.g., Jakobsson et al., 2000; Polyak et al., 2004; Löwemark et al., 2008; Adler et al., 2009). We identify 18 distinctly brown units, from B1 to B18, characterized by elevated content of Mn (Fig. 3). Another prominent lithostratigraphic feature in the western Arctic Ocean, widely used for core correlation, is pink-white to whitish layers (PW) rich in detrital carbonates (e.g., Clark et al., 1980; Polyak et al., 2009; Stein et al., 2010a, b). We identify three major PW layers expressed both visually and in high Ca content (Fig. 3). Lower Ca peaks occur throughout the record without being clearly expressed in the core macroscopic appearance.

Foraminiferal abundances are generally high (mostly $>50 \%$ of $>63 \mu \mathrm{m}$ grains) in brown units, except for B11B13 and below B17-B18, and are very low to absent in gray units. This pattern is consistent with foraminiferal stratigraphy reported in earlier studies from the western Arctic Ocean (e.g., cores NP-26, HLY0503-JPC6 and 8, P1-92ARP23 and 39: Polyak et al., 2004, 2013; Adler et al., 2009; Cronin et al., 2013; Lazar and Polyak, 2016). While only planktic foraminifers have been counted, data from correlative records indicate similar downcore variability in relative abundance of benthic foraminifers.

\subsection{AMS ${ }^{14} \mathrm{C}$ dating}

The measured AMS ${ }^{14} \mathrm{C}$ ages of core ARC4-BN05 were calibrated to calendar ages based on calibration using CALIB 7.10 (http://calib.org/calib/calib.html) (Table 2). The reservoir corrections of 790 and 1400 years were applied to Holocene and glacial-age samples, respectively, according to 


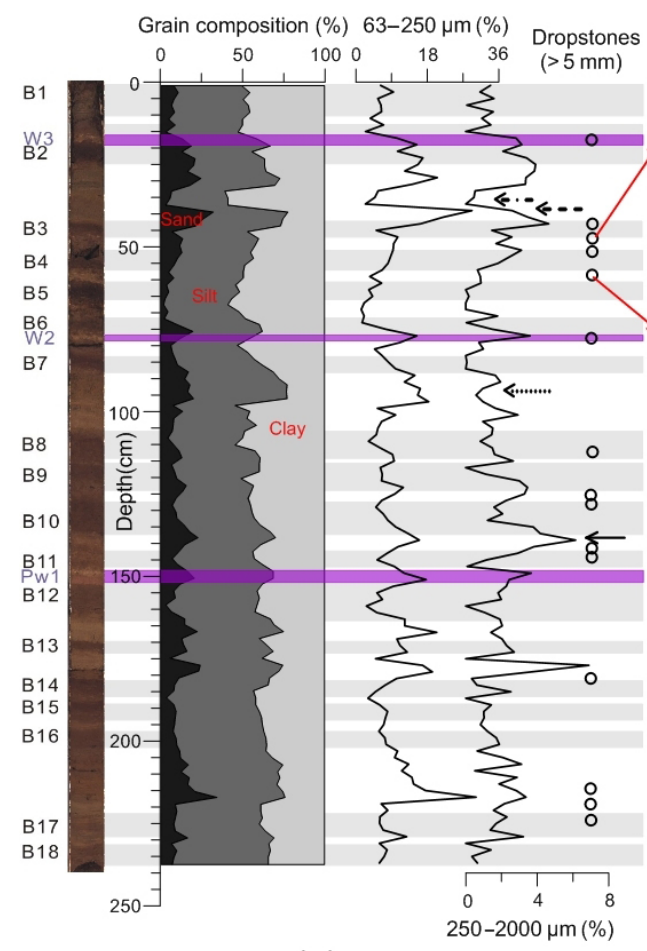

(a)

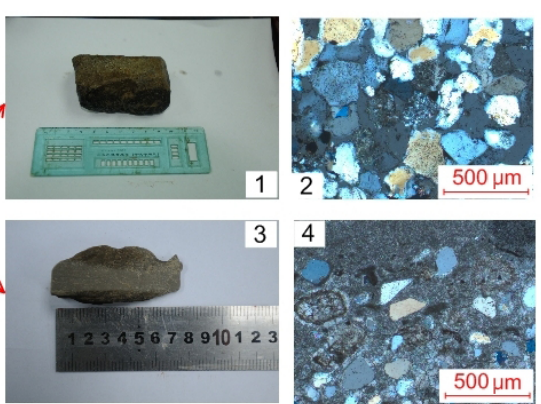

(c)

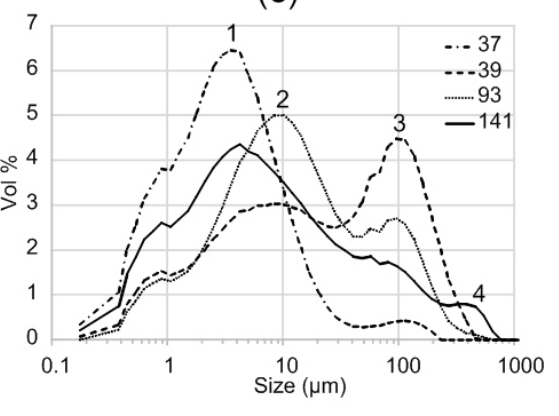

(b)

Figure 4. (a) Down-core grain-size distribution in core ARC4-BN05 (in volume \%): clay ( $<4 \mu \mathrm{m})$, silt $(4-63 \mu \mathrm{m})$, sand $(63-2000 \mu \mathrm{m})$, fine sand $(63-250 \mu \mathrm{m})$, and coarser sediment $(250-2000 \mu \mathrm{m})$. Occurrence of dropstones $>5 \mathrm{~mm}$ is shown by circles on the right. See Fig. 3 for lithostratigraphy explanation and Tables S1-S2 for data used. (b) Granulometric distribution types exemplifying major grain-size modes 1-4. Position of respective curves in core ARC4-BN05is indicated in the legend (depth in core, $\mathrm{cm}$ ) and is shown by arrows in (a). (c) Examples of dropstones from core ARC4-BN05. 1: 48-54 cm, quartz sandstone; 2: same dropstone, thin section in cross-polarized light; 3: 56-63.5 cm, dolomite dropstone; 4 : same dropstone, thin section in cross-polarized light.

Coulthard et al. (2010) and Hanslik et al. (2010). The same corrections have also been applied to ${ }^{14} \mathrm{C}$ ages in core $03 \mathrm{M} 03$ from the Chukchi Abyssal Plain (Wang et al., 2013; see Fig. 2 for location).

\subsection{Paleomagnetic stratigraphy}

While detailed paleomagnetic investigation is not an objective of this paper, we utilize the inclination data for an independent stratigraphic constraint in line with earlier studies (e.g., Jakobsson et al., 2000; Spielhagen et al., 2004; Polyak et al., 2009). Paleomagnetic inclination in core ARC4-BN05 shows mostly positive values oscillating around $+70^{\circ}$ in the upper part of the core, with a major polarity change occurring at $\sim 120 \mathrm{~cm}$ (Fig. 3). A similar inclination drop has been identified in multiple sediment cores across the Arctic Ocean in the same stratigraphic position within estimated MIS 7, although the nature of this change in paleomagnetic characteristics is not well understood (e.g., Jakobsson et al., 2000; Polyak et al., 2009; Xuan and Channell, 2010).

Other paleomagnetic parameters, such as magnetic susceptibility (MS), can provide additional correlation means (e.g., Sellén et al., 2010). Two prominent peaks in MS occur in the intervals between units B7/B8 and B10/B11 (Fig. 3).

\subsection{Grain size and dropstones}

Based on the results of grain-size analysis, sediment in core BN05 can be generally classified as sandy, poorly sorted mud (e.g., Blott and Pye, 2012). Overall, silt and clay predominate grain-size composition (33-60 and 23-61\%, respectively), but coarser particles also make a considerable contribution, with up to $>30 \%$ peak contents of sand (>63 $\mu \mathrm{m}$ ) (Fig. $4 \mathrm{a}$ ). We note that $4 \mu \mathrm{m}$ was used as a cutoff size between clay and silt to account for overestimation of fine sediment diameters by laser diffraction, especially in the presence of platy particles (Beuselinck et al., 1998; Ramaswamy and Rao, 2006). Coarse size fractions (63-250 and $>250 \mu \mathrm{m}$ ) mostly co-vary downcore.

Grain-size distribution is mostly polymodal with three distinct major modes centered at $\sim 4,7-7.5$, and $85-90 \mu \mathrm{m}$, plus a smaller but consistent mode at $\sim 400-450 \mu$ m (Fig. 4b), which can be approximated by clay $(<4 \mu \mathrm{m})$, silt, and sand size fractions, respectively. Mode $1(4 \mu \mathrm{m})$ is overall most common in core BN05, occurring mostly in combination 


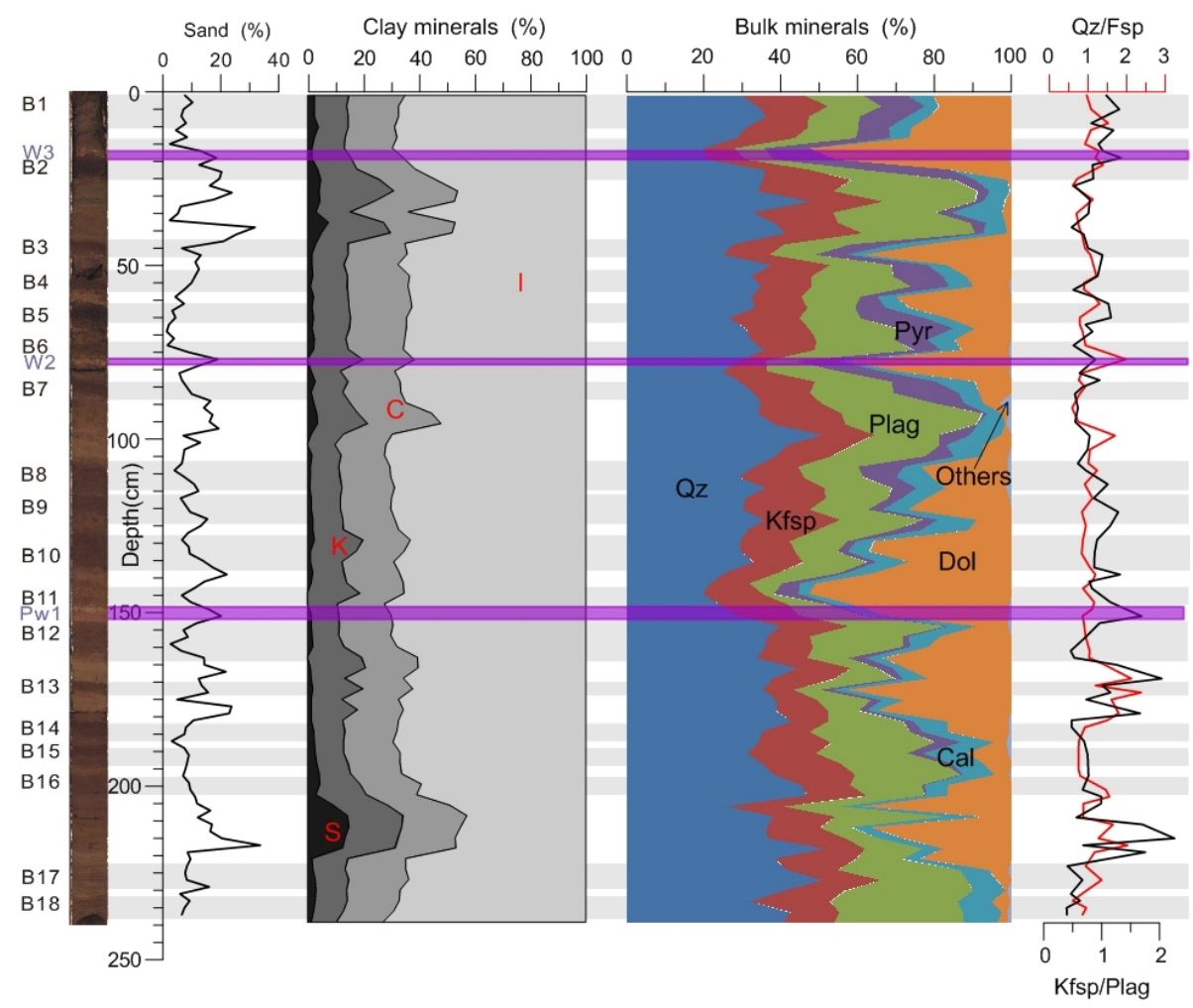

Figure 5. Relative weight contents of major clay mineral groups in the clay fraction $(<2 \mu \mathrm{m})$, bulk mineral composition and related indices in core ARC4-BN05. S, K, C, and I indicate smectite, kaolinite, chlorite, and illite, respectively. Qz, Kfsp, Plag, Pyr, Cal, and Dol are quartz, K-feldspar, plagioclase, pyroxene, calcite, and dolomite, respectively. See Fig. 3 for lithostratigraphy explanation and Table S1 for data used.

with the fine- and/or coarse-sand mode, but also forming very fine-grained intervals (e.g., at $37 \mathrm{~cm}$, Fig. 4b). Mode 2 $(7-7.5 \mu \mathrm{m})$ is common in the lower part of the core (below $\sim 175 \mathrm{~cm}$ ), where it mostly co-occurs with mode 1 and coarse-grain tail, and also in distinct gray units around 3040 and $90-100 \mathrm{~cm}$ in combination with the fine-sand mode 3 (e.g., 39 and $93 \mathrm{~cm}$, Fig. 4b).

Several core intervals contain large rock fragments $>5 \mathrm{~mm}$ (dropstones). These rock fragments are mostly poorly rounded, subangular to angular in shape. Composition of sampled dropstones is illustrated in Fig. 4c. Most dropstones are represented by dolomite and low metamorphic quartz sandstone fragments of up to $5 \mathrm{~cm}$ in diameter. Also found were individual dropstones composed of volcanic rock and shale, as well as a few greisen dropstones near the base of the core.

\subsection{Sediment mineralogy}

The clay assemblage in samples from core ARC4-BN05 mainly consists of illite, chlorite, kaolinite and smectite (Fig. 5). The illite group is overall the major constituent of the clay mineral fraction, ranging between 43 and $73 \%$. Its downcore distribution pattern is opposite to that of the three other major clay-mineral groups - kaolinite, chlorite, and smectite (mostly present in very low contents). These three groups largely co-vary except for some lithostratigraphic intervals, such as PW layers. Elevated content of these clay minerals is characteristic for grayish sedimentary units.

The bulk mineral assemblage in core ARC4-BN05 mainly consists of quartz, K-feldspar, plagioclase, calcite, dolomite and pyroxene (Fig. 5). Quartz is generally the most abundant mineral, ranging between 20 and $51 \%$ and typically peaking in grayish sediment units. K-feldspar, plagioclase and pyroxene (mainly augitic) mostly co-vary, with peaks in gray units in the upper part of the core, but more in brown units in the lower part starting from unit B10. Calcite has a high content in brown units of the upper part and much lower values below unit B9. Dolomite distribution shows distinct peaks reaching up to $53 \%$, with the highest peaks occurring in or adjacent to the PW layers. Similar to other minerals, the pattern of dolomite distribution changes around unit B10, with maxima in thick gray units below and in thin interlayers within brown units above this stratigraphic level.

\subsection{Principal component analysis}

The first five principal components identified by PCA with a Varimax rotation account for $77 \%$ of the total variance, with relatively evenly distributed communalities (Table 3). This 
BN05

PS72/392-5

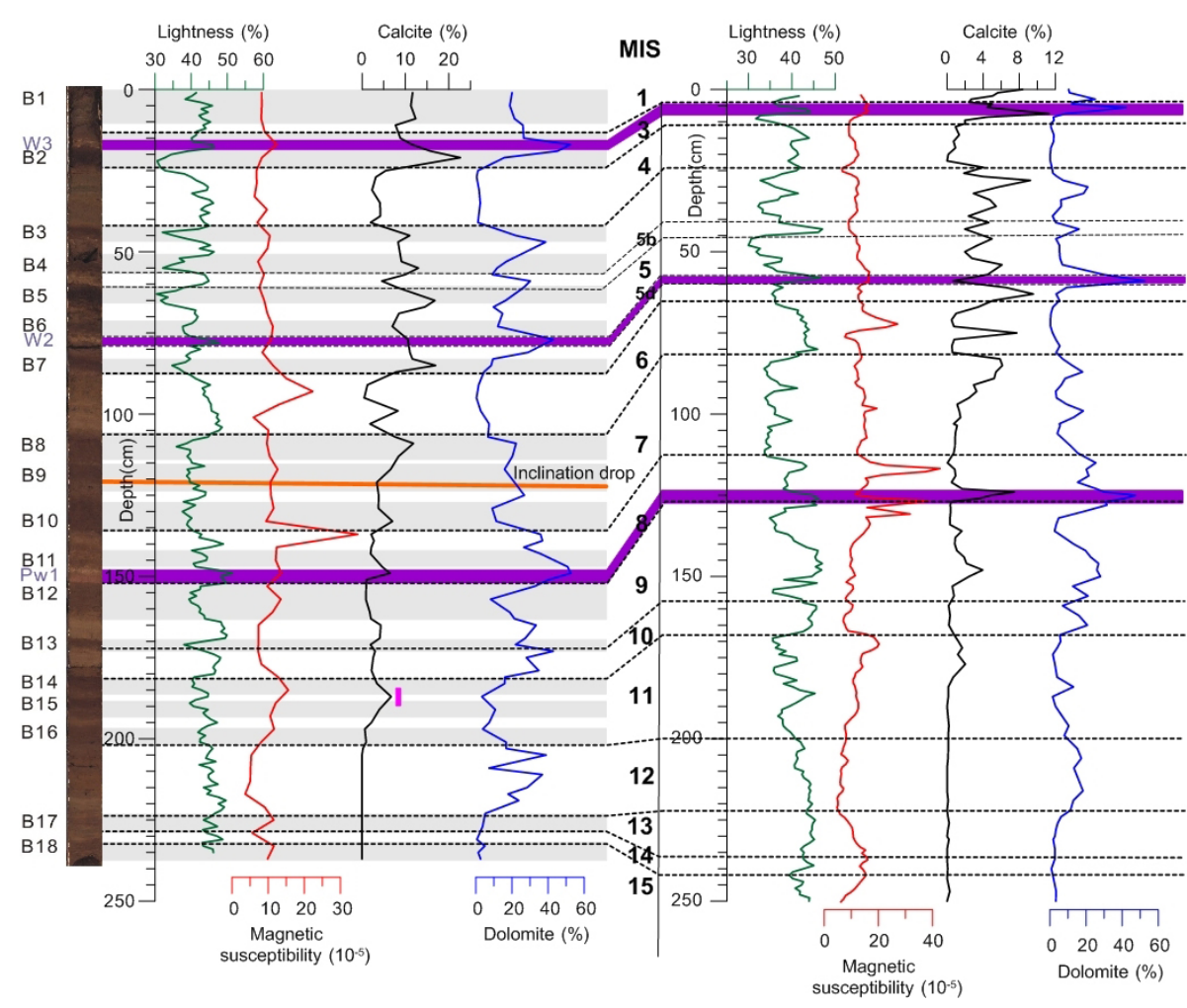

Figure 6. Stratigraphic correlation of core BN05 with PS72/392-5 (Stein et al., 2010a) based on sediment lightness, magnetic susceptibility, calcite and dolomite content. See Fig. 3 for other stratigraphic proxies and lithostratigraphy explanation. The vertical magenta bar indicates the position of the foraminiferal peak in B14-15.

pattern presumably reflects a complexity of multi-proxy variables characterizing sedimentary environments and provenance, as well as their strong variability occurring over multiple climatic cycles. To further test the PCA performance, we have also run a factor analysis with the maximum likelihood extraction, which produced similar factor loadings and variance explained, thus indicating the robustness of the results.

\section{Discussion}

\subsection{Stratigraphic framework}

As no single existing chronostratigraphic method can comprehensively constrain the age of the Arctic Ocean Pleistocene sediments, the age model for core ARC4-BN05 was developed by correlating multiple proxies (such as paleomagnetic, foraminiferal, and lithological; see Figs. 3 and 5), combined with ${ }^{14} \mathrm{C}$ ages in the youngest part of the record, to earlier established Arctic Ocean stratigraphies (e.g., Adler et al., 2009; Polyak et al., 2009, 2013; Stein et al., 2010a). Core PS72/392-5, raised very close to ARC4-BN05 and investigated in much detail (Stein et al., 2010a), was used to exemplify the correlation (Fig. 6).
The two ${ }^{14} \mathrm{C}$ dates from the uppermost, $10 \mathrm{~cm}$ thick brown sedimentary unit (B1) in core ARC4-BN05 clearly identify its Holocene age (Table 2; Fig. 3). Compilations of ${ }^{14} \mathrm{C}$ ages from the surficial and downcore sediments in the western Arctic Ocean (Polyak et al., 2009; Xiao et al., 2014) indicate that the age of this unit extends from $\sim 2-3 \mathrm{ka}$ on top to $\sim 10-11 \mathrm{ka}$ at the bottom contact, although an accurate estimate is impeded by the uncertainties with the reservoir ages.

Two ${ }^{14} \mathrm{C}$ dates of ca. $42-44 \mathrm{ka}$ from the brown unit B2 (Table 2; Fig. 3) apparently fall into MIS 3, consistent with earlier stratigraphic results (e.g., Polyak et al., 2004, 2009; Adler et al., 2009; Stein et al., 2010a). These ages should be, however, considered as crude estimates as they are close to the ${ }^{14} \mathrm{C}$ dating limit, and the age distribution in $\mathrm{B} 2$ has common inversions (e.g., Polyak et al., 2009). In cores with relatively elevated sedimentation rates this unit occurs as two distinct brown layers, indicated in some papers as B2a and B2b (e.g., Stein et al., 2010a, b; Wang et al., 2013). In core ARC4-BN05 this partitioning is less apparent due to low sedimentation rates, but the brownish sediment on top of the coarse detrital carbonate peak PW/W3, typically located between B2a and B2b, probably corresponds to B2a.

An abrupt increase in sediment age between closely spaced B1 and B2 in core ARC4-BN05 suggests a very con- 
Table 3. Loading scores for variables used in the PCA.

\begin{tabular}{|c|c|c|c|c|c|}
\hline & PC1 & $\mathrm{PC} 2$ & PC3 & $\mathrm{PC} 4$ & PC5 \\
\hline$\%$ of variance & 18.94 & 17.27 & 15.71 & 14.78 & 10.05 \\
\hline $\mathrm{Ca} / \mathrm{Al}$ & 0.18 & -0.07 & 0.62 & 0.57 & 0.18 \\
\hline $\mathrm{Mn} / \mathrm{Al}$ & 0.75 & -0.18 & -0.10 & 0.03 & -0.20 \\
\hline Clay (\%) & 0.77 & -0.44 & 0.03 & -0.19 & -0.25 \\
\hline Silt $(\%)$ & -0.80 & 0.17 & -0.13 & 0.07 & -0.41 \\
\hline Fine sand $(\%)$ & -0.34 & 0.50 & 0.02 & 0.21 & 0.64 \\
\hline$>250 \mu \mathrm{m}(\%)$ & -0.19 & 0.12 & 0.26 & 0.09 & 0.86 \\
\hline $\begin{array}{l}\text { Plankt. foram. } \\
(\%>63 \mu \mathrm{m})\end{array}$ & 0.78 & -0.06 & -0.06 & 0.04 & -0.34 \\
\hline Smectite $(\%)$ & -0.18 & 0.80 & 0.05 & -0.11 & -0.10 \\
\hline Illite (\%) & 0.17 & -0.96 & 0.04 & 0.03 & -0.17 \\
\hline Kaolinite (\%) & -0.17 & 0.76 & 0.13 & 0.07 & 0.41 \\
\hline Chlorite $(\%)$ & -0.01 & 0.70 & -0.42 & -0.07 & -0.01 \\
\hline Quartz (\%) & -0.30 & 0.18 & -0.47 & -0.08 & -0.04 \\
\hline K-feldspar (\%) & -0.03 & 0.16 & -0.02 & -0.91 & 0.07 \\
\hline Plagioclase (\%) & -0.15 & 0.09 & -0.78 & -0.48 & -0.12 \\
\hline Calcite $(\%)$ & 0.87 & -0.05 & 0.07 & 0.27 & -0.05 \\
\hline Pyroxene (\%) & -0.11 & -0.18 & -0.28 & -0.69 & -0.27 \\
\hline Dolomite (\%) & -0.05 & -0.12 & 0.72 & 0.56 & 0.15 \\
\hline $\mathrm{Qz/Fsp}$ & -0.12 & 0.06 & 0.28 & 0.66 & 0.10 \\
\hline Kfsp/Plag & -0.11 & 0.05 & 0.89 & -0.05 & 0.11 \\
\hline
\end{tabular}

Scores $>0.5(<-0.5)$ are highlighted in bold.

densed section or a hiatus between MIS 1 and MIS 3. This age distribution is common for the western Arctic Ocean and has been attributed to very low to no sedimentation due to a very solid sea-ice cover or an ice shelf during the LGM in MIS 2 (e.g. Polyak et al., 2009; Wang et al., 2013).

Below the range of ${ }^{14} \mathrm{C}$ ages the age model is based entirely on proxy correlations with earlier developed Arctic Ocean stratigraphies (e.g., Fig. 6). This correlation is enabled by the cyclic nature of sediment lithology and attendant proxies, where brown and grayish units generally correspond to interglacial (or major interstadial) and glacial climatic intervals, respectively (e.g., Jakobsson et al., 2000; Polyak et al., 2004, 2009; Adler et al., 2009; Stein et al., 2010a, b). In addition, correlation tie points are provided by rare or unique events, such as prominent detrital carbonate peaks (PW/W), major paleomagnetic inclination swings, and changes in foraminiferal assemblages and abundance pattern.

According to this approach, we identify foraminifera- and Mn-rich brown units B3-B7 and B8-B10 as warm substages of MIS 5 and 7, respectively (Figs. 3 and 6). This age assignment is corroborated by the prominent detrital carbonate peaks PW 2 and 1 near the bottom of MIS 5 and 7, respectively. Furthermore, the principal drop in paleomagnetic inclination in core ARC4-BN05 occurs in the lower part of MIS 7, consistent with many cores from the Arctic Ocean (e.g., Jakobsson et al., 2000; Spielhagen et al., 2004; Adler et al., 2009; Polyak et al., 2009). A solidly grayish, foraminifera- and Mn-poor unit separating brown units B2 and B3 is accordingly considered as related to glacial MIS 4, and a similar unit between B7 and B8 related to MIS 6. It is possible, however, that most of the fine-grained, grayish sediment was deposited during deglaciations following the actual glacial intervals, which may have been very compressed, similar to the LGM.

Stratigraphy below MIS 7 has been less investigated in prior studies, and is more difficult to address due to often less distinct units and scarce to absent foraminifers, probably resulting from stronger dissolution (e.g., Lazar and Polyak, 2016). Therefore the age model for the lower part of the core is more tentative. Nevertheless, a prominent oldest foraminiferal peak in units B14-B15 (Fig. 3) allows us to identify these units as MIS 11 by comparison with other microfaunal records reported from the western Arctic Ocean (e.g., Cronin et al., 2013; Polyak et al., 2013). While individual species have not been counted in ARC4-BN05, predominant planktic foraminifers in this peak are identifiable as Turborotalitaegelida, constituting a unique event in the Arctic stratigraphy (see Cronin et al., 2013, 2014, for more detail). MIS 13 and 15 have been tentatively assigned to units B17 and B18 underlying a prominent gray interval attributed to MIS 12. Overall, the record in core ARC4-BN05 is estimated to represent the last ca. $0.5-0.6 \mathrm{Ma}$, that is, most of the middle to late Quaternary with an average sedimentation rates of $4-5 \mathrm{~mm} \mathrm{kyr}^{-1}$.

\subsection{Depositional environments and sediment provenance}

Distribution of various terrigenous components in Arctic sediment records carries information on sediment sources and depositional environments, and thus paleocirculation and changes in paleoclimatic conditions, such as connection to other oceans and build-up/disintegration of ice sheets (e.g., Bischof and Darby, 1997; Krylov et al., 2008; Polyak et al., 2009; Stein et al., 2010a, b; Yurco et al., 2010; Fagel et al., 2014). We utilize the data on clay and bulk minerals along with the grain size and total $\mathrm{Ca}$ and $\mathrm{Mn}$ distribution in core ARC4-BN05 to reconstruct changes in glacial conditions and circulation in the western Arctic Ocean during several glacial cycles extending to estimated ca. 0.5-0.6 Ma. In this work we capitalize on earlier studies on the distribution of bulk and/or clay minerals in surface and downcore Arctic Ocean sediments (e.g., Vogt, 1997; Stein, 2008; Krylov et al., 2014; Zou, 2016), corroborated by more targeted provenance proxies, such as radiogenic isotopes (Fagel et al., 2014; Bazhenova et al., 2017), heavy minerals (Stein, 2008; Kaparulina et al., 2016), composition of coarse debris (Bischof et al., 1996; Wang et al., 2013), and iron oxide grains (e.g., Bischof and Darby, 1997; Darby et al., 2002). To optimize the PCA results for clarifying relationships between various sedimentary proxies, we plotted the leading PC loading scores as biplots in the PC 1-2 and PC 3-4 space (Fig. 7a). These plots help to identify several sedimentary variable groups with high loadings ( $>0.7$ average) in at least one of the lead- 
(a)
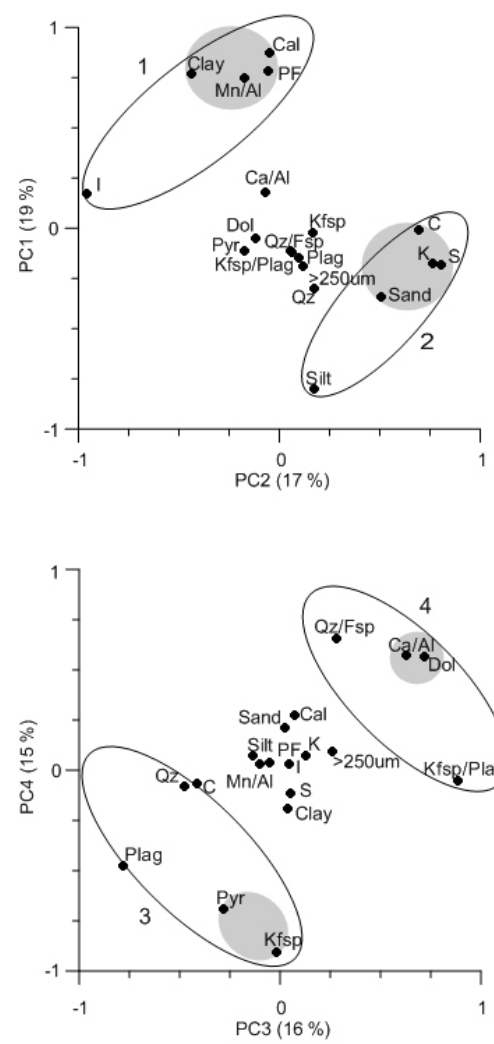

(b)

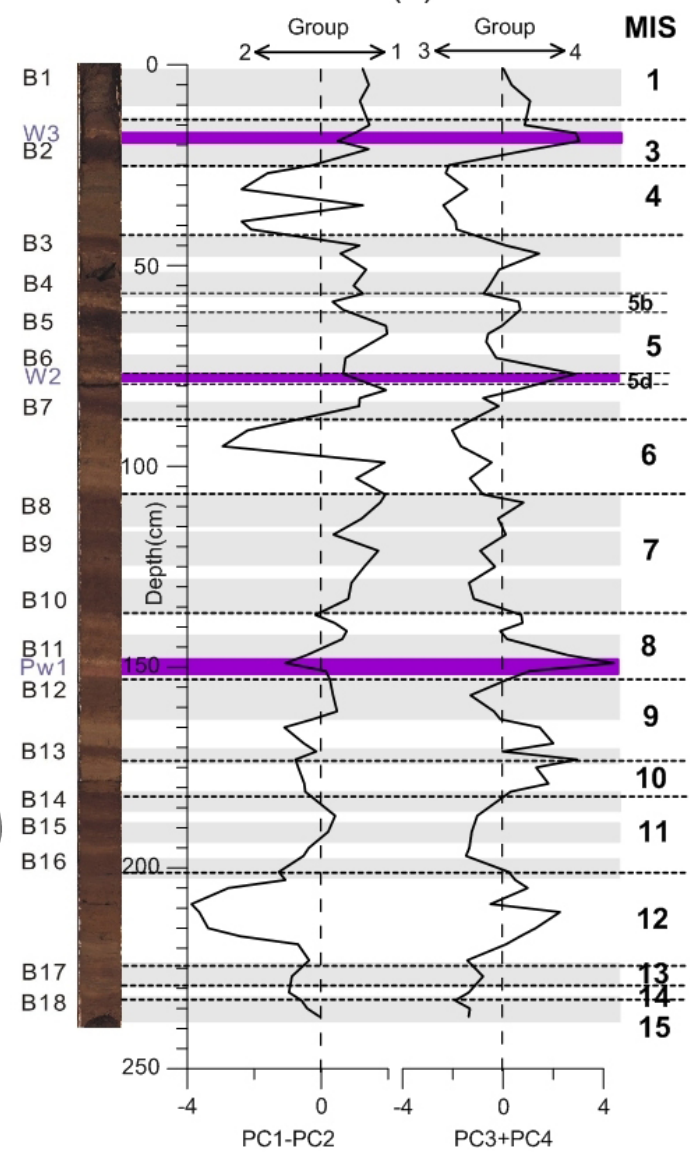

Figure 7. (a) Biplots of principal component loading scores in PC 1-2 and PC 3-4 space (see Table 3 for loading data and Table S3 for correlation between variables). Sedimentary variable groups revealed by the loading distribution are enclosed by ellipses and numbered, with the closest groupings highlighted in gray. (b) Downcore distribution of sedimentary variable groups plotted using combined PC 1-2 and PC 3-4 scores (see Table S4 for score data).

ing PCs. Group 1 consists of various proxies characteristic of brown layers (primarily $\mathrm{Mn}$, foraminifera, calcite, and clay, with an apparent affinity to chlorite). The opposing group 2 includes most clay minerals except chlorite, with a proximity to sand and, to a lesser extent, silt size fractions. Bulk mineralogy proxies are largely represented by the opposing groups 3 and 4 . Group 3 comprises feldspar, pyroxene, and more distant quartz and plagioclase. Group 4 builds around dolomite that has high loading scores in both PC 3 and 4, along with bulk $\mathrm{Ca}$, and shows affinity to Kfsp/Plag and Qz/Fsp indices. In addition to these groups revealed by the leading PC biplots, PC 5 (10\% variance) shows high scores for sand and coarser sediment, with silt as the main opposing variable.

To gain insight into stratigraphic changes in sedimentary environments and provenance, we plotted the distribution of the identified variable groups $1-4$ using the combined downcore scores of PC 1-2 and PC 3-4 (Fig. 7b). A combination of the PC group composition and downcore variability provides useful guidance for interpreting major sedimentary controls and their stratigraphic evolution.

\subsubsection{Grain size and depositional processes}

A variable, mostly multimodal distribution of grain size in core BN05 indicates multiple controls on sediment delivery and/or deposition. The prevailing mode 1 at $\sim 4 \mu \mathrm{m}$ (Fig. $4 \mathrm{~b}$ ), often in variable combinations with the fine-sand mode, is common for brown units, except for the oldest layers (B16B18; estimated MIS 13/15 and partly 11; Fig. 6). This granulometric pattern is similar to grain-size distribution with an average mode at $\sim 3.4 \mu \mathrm{m}$ reported for Holocene sediments across the Arctic Ocean (Darby et al., 2009). Furthermore, sediment in core BN05 with the same mode also makes up the most fine-grained intervals in glacial/deglacial units, such as MIS 4 and 6 (at $\sim 30-40$ and $100-110 \mathrm{~cm}$; Fig. 4b). We infer that mode 1 represents some combination of deposition from sea ice and from suspension that could result from winnowing of fines from the basin margins and ridges during 
interglacials, as well as overflow plumes discharged by retreating glaciers during glacial/deglacial intervals. An occurrence of apparently similar grain-size pattern in interglacial and fine-grained glacial/deglacial intervals might indicate a convergence of glacial erosion processes with those related to sea-ice formation and transportation. A similar grain-size interpretation has been earlier proposed for sediment from the Canada Basin with the principal mode at $\sim 2 \mu \mathrm{m}$ (Clark et al., 1980). This apparent discrepancy may be related to the methodological offset between grain size determined by the pipette method vs. laser diffraction, where the latter produces larger diameters for fine sediment, especially in the presence of platy particles (Beuselinck et al., 1998; Ramaswamy and Rao, 2006).

Mode 2, centered at 7-7.5 $\mu \mathrm{m}$, is more stratigraphically restricted. Its combination with the fine-sand mode (e.g., Fig. 4b) is characteristic for coarser-grained portions of MIS 4, 6, and 12 ( 25-30, 40-45, 90-95, and 205-215 cm), which also have a specific mineralogical composition (sedimentary variable group 2: Fig. 7; Table 3). This stratigraphic pattern suggests that the formation of this sediment was related to glacial/deglacial processes; however, the prevailing grain-size mode around $7-7.5 \mu \mathrm{m}$ is distinctly coarser than in deglacial intervals characterized by mode 1 and likely deposited from suspension plumes, which suggests a different sedimentation regime. While being too fine-grained for massive deposition from icebergs, fine to medium silts are susceptible to intermediate currents and are thus common for turbiditic deposits, including glacigenic environments (e.g., Wang and Hesse, 1996; Hesse and Khodabaksh, 2016). We propose that mode 2 sediment type is related to glacial underflows that formed debris lobes on glaciated margins grading into turbidites in the adjacent basins, along with iceberg-rafted debris. Multiple debris lobes have been mapped on the Chukchi and East Siberian slopes in association with glacigenic diamictons on the margin (Jakobsson et al., 2008; Niessen et al., 2013; Dove et al., 2014). Close to the margins, glacioturbidites can form deposits of several meters thick (Polyak et al., 2007) but thin out towards the inner parts of the basins, such as the BN05 site. In particular, deposits similar to fine-grained turbidites, attributed to MIS 4/lower MIS 3, have been recovered from the Northwind and Chukchi basins, affected by glacigenic inputs from the Chukchi and East Siberian margins, respectively (Polyak et al., 2007; Matthiessen et al., 2010; Wang et al., 2013). In the Chukchi Basin this unit, correlative to a much thinner MIS 4 interval in core BN05, is characterized by a high content of fine silt with a peaky downcore distribution (Wang et al., 2010, 2013).

Additionally, modes 1 and 2 make up a bimodal distribution in the lowermost part of the core - mostly in estimated MIS 13/15 and near the bottom of MIS 11. The predominant stratigraphic position in brown units makes the glacigenic origin of this sediment unlikely. We hypothesize that this grain-size pattern reflects a combination of "normal" interglacial environments with winnowed silts deposited by downwelling of shelf waters enriched in dense brines. Although no observational evidence exists for such waters penetrating deeper than the halocline $(\sim 200 \mathrm{~m})$ under modern Arctic conditions, periods of stronger cascading in the past have been inferred from sediment distribution on the slopes (Darby et al., 2009) and some sedimentary proxies, such as radiogenic isotopes (Haley and Polyak, 2013; Jang et al., 2013). The bimodal distribution of fine sediment in the lower part of the record is accompanied in most samples by a small but consistent coarse-sand mode $(400-450 \mu \mathrm{m})$, likely indicating the presence of iceberg rafting.

Coarse sediment, up to dropstones of several centimeters large, is a consistent feature in core BN05. In the apparent absence of strong current control on sedimentation, except for some shelf areas, and a pervasive presence of floating ice, coarse sediment in the Arctic Ocean is typically attributed to ice rafting, including sea ice and icebergs (e.g., Stein, 2008; Polyak et al., 2010, and references therein). Sedimentological studies in areas of sea-ice formation or melting and in ice itself indicate that sediment carried by sea ice in the Arctic Ocean is predominated by silt and clay, while coarser fractions are of minor importance (Clark and Hanson, 1983; Nürnberg et al., 1994; Hebbeln, 2000; Darby, 2003; Dethleff, 2005; Darby et al., 2009). Some studies suggest a higher content of sand in ice formed at the sea floor (anchor ice) (Darby et al., 2011), but the contribution of this source still needs to be evaluated. Furthermore, the role of sea ice on sedimentation in the Arctic Ocean is not clear for glacial intervals, when most of the sediment entrainment areas were exposed or covered by ice sheets. In contrast, in iceberg-rafted sediment, deposited mostly in glacial/deglacial environments, the content of large size fractions, from sand to boulders, is typically high, in excess of 10-20\% (Clark and Hanson, 1983; Dowdeswell et al., 1993; Andrews, 2000). Thus, elevated content of coarse sediment can be regarded as a good indicator of intense iceberg rafting. Such events are not probable during full interglacials, exemplified by modern conditions, but most likely occurred at times of instability and disintegration of ice sheets that extended to the Arctic Ocean in the past (e.g., Spielhagen et al., 2004; Stokes et al., 2005; Polyak et al., 2009).

In core BN05, coarse fractions (from coarse silt to sand) measured at different sizes show very similar distribution patterns (Fig. 4a), indicating the same predominant delivery mechanism, that is, iceberg rafting. This pattern is reflected in a good correlation of fine to medium sand (63$250 \mu \mathrm{m}$ ) with coarser, $>250 \mu \mathrm{m}$ fractions, that defines one of the principal components (PC 5: Table 3). Increased coarsegrain content mostly characterizes grayish units, especially near gray-to-brown sediment transitions, and the PW layers, but also occurs in brown units in the upper part of the record. The latter peaks enriched in detrital carbonates (high dolomite and total $\mathrm{Ca}$ ) represent interstadial or incomplete 
interglacial conditions, such as MIS 3, MIS 5a, and parts of MIS 7 (Fig. 6).

A common occurrence (separate or combined) of two coarse grain modes, around $85-90$ and $400-450 \mu \mathrm{m}$, may indicate different sources for iceberg-rafted material or different thresholds for glacial disintegration of various rock types. While a more thorough interpretation requires further research, we note that grain-size mode 1 may co-occur with both fine- and coarse-sand modes, mode 2 only with the finesand mode, and bimodal $1 / 2$ sediment type only with the coarse-sand one.

\subsubsection{North American provenance}

One of the most robust sedimentary variable groups is distinctly characterized by high loadings of dolomite along with total Ca content (group 4: Fig. 7a, Table 3). Dolomite has been proposed as the main contributor of $\mathrm{Ca}$ in sediment cores from the western Arctic Ocean, with an especially high content in multiple coarse-grain peaks of detrital carbonates (Bischof et al., 1996; Phillips and Grantz, 2001; Polyak et al., 2009; Stein et al., 2010a, b). A high correlation $(r=0.81)$ and consistent $\mathrm{PC}$ grouping of dolomite and total $\mathrm{Ca}$ (Fig. 7a) corroborates their affinity in ARC4-BN05, although calcite can also contribute to Ca content $(r=0.58)$, especially in interglacial intervals with high foraminiferal numbers. We note that total Ca may be a redundant proxy in the presence of dolomite and calcite data; however, it is convenient for a comparison with a growing number of cores analyzed for elemental composition using XRF scanners (e.g., Löwemark et al., 2008; Polyak et al., 2009).

The main western Arctic source for dolomite is the extensive, carbonate-rich Paleozoic terrane in northern Canada (North American Platform; Fig. 1; Okulitch, 1991; Harrison et al., 2008). During the Pleistocene this terrane was repeatedly impacted by the LIS with a subsequent transport of eroded material into the western Arctic Ocean (e.g., Stokes et al., 2005; England et al., 2009). The distribution of dolomite in Arctic sediment cores is thus a robust indicator of the North American provenance and can be used for reconstructing the history of the LIS sedimentary inputs.

Consistent with other cores from the western Arctic Ocean, overall high dolomite content in core ARC4-BN05 has major peaks corresponding to visually identifiable $\mathrm{PW} / \mathrm{W}$ layers enriched in coarse debris (Fig. 5). As has been suggested in earlier studies (e.g., Stokes et al., 2005; Polyak et al., 2009), we infer that the dolomite peaks are related to pulses of massive iceberg discharge from the LIS during the periods of its destabilization and disintegration. Furthermore, radiogenic isotope studies demonstrate that fine sediment in the dolomitic peaks also has North American provenance (Fagel et al., 2014; Bazhenova et al., 2017). These results indicate that dolomite may have been transported not only by icebergs but also in meltwater plumes coming during deglaciations from the Canadian Archipelago or the Mackenzie River.

As noted above, a change in the stratigraphic pattern of dolomite distribution occurs around unit B10 estimated to correspond to the lower part of MIS 7 (Fig. 6). In older sediments dolomite maxima co-occur with glacial (predominantly gray) intervals, whereas in the younger stratigraphy dolomite peaks in brown sediment or grayish interlayers within brown units (MIS 3, 5, and 7), presumably corresponding to transitional paleoclimatic environments, such as interstadials or stadials within complex interglacial stages.

Other potential mineral indicators related to the North American provenance are quartz/feldspar and Kfeldspar/plagioclase ratios as exemplified by the BN-05 PCA results (group 4: Fig. 7a), consistent with earlier studies (e.g., Vogt, 1997; Zou, 2016; Kobayashi et al., 2016). High Qz / Fsp ratio has been related to a considerable presence of sedimentary rocks enriched in quartz, but not feldspar, in the Canadian Arctic in comparison with the Siberian margin (Vogt, 1997; Zou, 2016; Kobayashi et al., 2016). In core ARC4-BN05 the distribution of this index is generally similar to dolomite (Fig. 5), except for some coarse-grain peaks, notably low Qz/Fsp values in PW 1 and 3, resulting in an overall lower correlation $(r=0.46)$. This pattern may be related to grain-size variance or might reflect provenance differences. Low plagioclase content has also been identified for intervals with high detrital inputs from the Canadian Arctic (Vogt, 1997; Zou, 2016). Especially high Kfsp/Plag values accompany dolomitic peaks in the older glacial intervals corresponding to MIS 12 and 10 (Figs. 5 and 6).

\subsubsection{Siberian provenance}

Mineral proxies potentially linked to Siberian provenance make two distinct groups, as reflected in the PCA results (groups 2 and 3: Fig. 7a, Table 3). Group 3 comprises primarily pyroxene, feldspar, and plagioclase, and strongly anticorrelates with the North American proxies, primarily dolomite. The downcore distribution pattern of this group changes from the affinity to interglacials in the lower part of the record to peaks in glacial/deglacial intervals related to MIS 4 and 6 (Fig. 7b). The major source for pyroxene in the Arctic Ocean is the Siberian trap basaltic province that drains to the Kara Sea and western Laptev Sea (Fig. 1; Washner et al., 1999; Schoster et al., 2000; Krylov et al., 2008). However, basaltic rocks related to the Okhotsk-Chukotka province (Fig. 1) may have also provided a significant source of pyroxenes, as exemplified in surface sediments by a relative pyroxene enrichment in the Chukchi Basin on the background of overall low values in the western Arctic Ocean (Dong et al., 2014). Distributions of feldspar and plagioclase at the Siberian margin show elevated contents occurring both in the western Laptev Sea and the East Siberian Sea (Zou, 2016).

Based on a considerable affinity of the pyroxene-feldspar group to brown units and a lack of correlation with coarse 
sediment fractions, we infer that it is primarily related to sea-ice transport during interglacial/deglacial intervals, with sources potentially including the East Siberian margin and more westerly areas. The difference in both the sources and delivery processes from the LIS proxies may explain an especially strong opposition of these groups. Multiple studies suggest that sea ice from the Kara and Laptev seas may transport sediments to the Canada Basin under favorable atmospheric conditions, such as the positive phase of the Arctic Oscillation (Behrends, 1999; Darby, 2003; Darby et al., 2004, 2012; Yurco et al., 2010), although it remains to be investigated to what extent this circulation pattern could have provided a significant sediment source for the western Arctic Ocean in the Pleistocene.

\subsubsection{East Siberian Ice Sheet}

Another leading sedimentary variable group comprises primarily clay minerals smectite, kaolinite, and chlorite, and shows affinity to coarse sediment, especially consistently to fine sand (63-250 $\mu \mathrm{m})$ (group 2: Fig. 7a, Table 3). This composition is especially characteristic for intervals estimated as MIS 4, 6, and 12. The association of clay minerals with coarse sediment (correlation reaching as high as $r=0.65$ for kaolinite) is unusual and suggests that they may have been derived by glacial erosion of source hard rocks. This linkage has been elaborated for kaolinite distribution in the Barents Sea and central Arctic Ocean (Junttila, 2007; Vogt and Knies, 2009; Krylov et al., 2014). While kaolinite sources, such as Meso-Cenozoic paleosols and shales, are mostly known in the western Arctic from northern Alaska and Canada (Naidu et al., 1971; Darby, 1975; Dalrymple and Maass, 1987), kaolinite weathering crusts have also been described from the East Siberian margin (Slobodin et al., 1990; Kim and Slobodin, 1991). Smectite, which is typically related to chemical weathering of basic rocks has been mostly associated in Arctic sediments with delivery from Siberian trap basalts (Fig. 1) as reflected in the surface sediments, suspended particulate material, and sea-ice samples from the Kara Sea and western Laptev Sea (Stein et al., 1994; Wahsner et al., 1999; Schoster et al., 2000; Dethleff et al., 2000). Peaks of smectite related to that source are especially charcteristic for deglacial intervals in sediment cores from the eastern Arctic Ocean (Vogt and Knies, 2008). However, considerable sources of smectite also exist further east along the Siberian margin due to basaltic outcrops related to the Okhotsk-Chukotka volcanic province (Fig. 1), resulting in a high content of smectite in surface sediments of the East Siberian and Chukchi seas (Naidu et al., 1982; Viscosi-Shirley et al., 2003; Nwaodua et al., 2014). Chlorite is also common in surface sediments and suspended particulate material at the East Siberian margin (Dethleff et al., 2000; Viscosi-Shirley et al., 2003). Modern and Holocene sediments on the Chukchi shelf are especially enriched in chlorite due to advection from the North Pacific at high sealevel stands (Kalinenko, 2001; Ortiz et al., 2009; Nwaodua et al., 2014; Kobayashi et al., 2016); however, this mechanism is only applicable to interglacial periods.

We infer that sediment with a concerted enrichment in smectite, kaolinite, and chlorite clay minerals associated with coarse fractions was transported to the Canada Basin primarily in relation to the existence of large ice sheets in northern East Siberia during glacial periods. Radiogenic isotope signature in upper Quaternary records from the Mendeleev Ridge also indicates that the Okhotsk-Chukotka volcanic rocks provided one of the principal end members, especially during MIS 4 and 6 (Fagel et al., 2014; Bazhenova et al., 2017). This sediment had to be transported into the Arctic Ocean directly from the East Siberian/Chukchi margin as the alternative pathway via the Bering Sea only operated at high interglacial sea levels, when the Bering Strait was open for throughflow (e.g., Keigwin et al., 2006; Ortiz et al., 2009). Considering an affinity of the kaolinitesmectite-chlorite group with sediments coarser than clays, corresponding to grain-size modes 2 and 3, their distribution across the basin was likely related to iceberg rafting and glacial underflows, as discussed above in Sect. 5.2.1. A relatively fast and direct delivery mechanism by debris flows and ensuing turbidites may explain a good preservation of fragile clay minerals, normally not resistant to physical erosion.

Some early paleoglaciological studies proposed the existence of a thick Pleistocene ice sheet centered over the East Siberian shelf (Hughes et al., 1977; Grosswald and Hughes, 2002). The inference of former ice sheets/shelves in this region is now corroborated by multibeam bathymetry and sub-bottom data revealing multiple glacigenic features on the top and slopes of the Chukchi and East Siberian margin (Polyak et al., 2001, 2007; Jakobsson et al., 2008, 2014, 2016; Niessen et al., 2013; Dove et al., 2014). ESIS has also been reproduced by numerical paleoclimatic modeling for a large Pleistocene glaciation exemplified by MIS 6 (Colleoni et al., 2016). Sedimentary proxies indicative of the OkhotskChukotka provenance in cores from the Canada Basin may provide an additional tool for reconstructing the ESIS history.

\subsubsection{Interglacial signature}

Data points from brown units make up a distinct sedimentary variable group with $\mathrm{Mn}$, foraminiferal numbers, calcite, and fine sediment as lead variables (group 1: Fig. 7a; Table 3). This composition is consistent with the modern-type Arctic Ocean environments characterized by predominant controls of sediment deposition by sea ice, considerable biological activity in summer, and high sea levels. The last of these is important for providing supply of Mn from the surrounding shelves (März et al., 2011; Löwemark et al., 2014). The same condition may also control biological production, and thus foraminiferal numbers, via export of nutrients from the marginal seas (e.g., Xiao et al., 2014), although interaction of this factor with sea-ice conditions still needs to be clarified. 
We note that the absence (dissolution) of foraminiferal tests in brown units corresponding to MIS 9 and below MIS 11 likely weakens their relationship to other interglacial proxies. Nevertheless, the foraminiferal variable shows a consistent proximity to Mn, clay, and calcite in the PCA results (Fig. 7a).

The mineral having the closest distribution to the main constituents of PC group 1 is illite, consistent with a predominant occurrence in brown, interglacial/major interstadial units (Figs. 5 and 7a). Illite is atypical high-latitude clay mineral, mainly supplied by physical weathering of metasedimentary and plutonic rocks (Chamley, 1989; Junttila, 2007). High illite concentrations in surficial Arctic Ocean sediments have been found in many areas including the Alaska margin and adjacent Canada Basin (Dong et al., 2014; Kobayashi et al., 2016), East Siberian Sea and the adjacent part of the Laptev Sea (Wahsner et al., 1999; Kalinenko, 2001; ViscosiShirley et al., 2003; Dethleff, 2005; Zou, 2016), and northern Greenland and Svalbard regions (Stein et al., 1994). In core ARC4-BN05 illite has consistently high values in generally fine-grained brown units (Fig. 5), although peak values may not exactly coincide with those of $\mathrm{Mn}$ or foraminiferal numbers. In addition, illite shows a prominent peak in a very finegrained interval at $\sim 35 \mathrm{~cm}$ within glacial/deglacial sediment of estimated MIS 4. This distribution is consistent with the pattern in both surface sediments and sediment cores, where illite is characteristic for fine-grained sediment indicative of transportation by sea ice or in the water column (Krylov et al., 2014). As shown by sediment-core studies, these mechanisms can provide high illite levels under both interglacial (this study) and glacial/deglacial environments (Knies and Vogt, 2003; Yurco et al., 2010). The latter is probably associated with deposition of fine sediment from glacial overflows, as exemplified by the fine-grained part of MIS 4 deglaciation.

High contents of calcite in core ARC4-BN05 mostly cooccur with high numbers of foraminifers (Fig. 7a; Table 3), indicating that calcite in these sediments is to a large extent biogenic, consistent with earlier results from the study area (Stein et al., 2010a). Nevertheless, in the lower part of the record, where calcareous fossils are mostly not preserved, calcite shows a considerable affinity to dolomite, which corroborates a mixed, biogenic and detrital nature of calcite in Arctic Ocean sediments (e.g., Vogt, 1997).

\subsection{Evolution of sedimentary environments}

The stratigraphically changing pattern of sediment delivery and deposition, including cyclic glacial-interglacial fluctuations and longer-term changes, indicates complex interactions of climatic and oceanographic factors controlling depositional environments in both glacial and interglacial intervals. A long-term trend in interglacial environments is indicated by a shift from predominantly Siberian to more North American provenance, especially strong in MIS 5 and 1 , and increasingly high scores of interglacial proxies (group 1), with a threshold around the bottom of MIS 7 (Fig. 7b). Glacial environments show an apparently more complex provenance change, with Siberian sources predominating MIS 4 and 6, and Laurentide provenance controlling MIS 8 and 10 (Fig. 7b). Earlier glaciations, exemplified by a prominent MIS 12 unit, have a mixed signature of high smectite and dolomite contents, likely reflecting a combination of East Siberian and LIS inputs. In addition, an interglacial-type signature (group 1) characterizes some intervals in MIS 4 and 6 as well as intermittent (stadial) intra-MIS 3, 5, and 7 events. We note that MIS 2 is not represented in these data due to its very compressed nature.

\subsubsection{Glacial environments}

The identified changes in sedimentary environments and provenance can be explained by several types of controls, including configuration of ice sheets against sea level and climatic conditions, sediment delivery mechanisms, and circulation. Ice sheet sites and geometry at specific time intervals dictate the timing and location of major sediment discharge events into the Arctic Ocean. Transportation mechanisms, such as by icebergs, debris flows, or suspension plumes, further control sediment delivery to specific sites. Finally, oceanic circulation affects the distribution of sediment across the oceanic basins. This may include surface circulation driving sea ice, icebergs, and surface plumes; deep circulation affecting turbidite/contourite pathways; and downwelling of sediment-laden dense waters.

We infer that sedimentary variations observed in core BN05 and correlative records from the western Arctic Ocean can be explained by the evolution of surrounding ice sheets and associated changes in oceanic conditions, such as circulation, sea ice, and biota. It has been known from early studies (e.g., Clark et al., 1980; Winter et al., 1997) that glacial, notably LIS, impact on the western Arctic Ocean has been steadily increasing over the time span covered by sediment cores from this region. A recent investigation utilizing a more up-to-date stratigraphic paradigm estimated the timing of a step increase in LIS inputs as ca. 0.8 Ma (Polyak et al., 2013), consistent with the onset of major glaciations in the Northern Hemisphere (Head and Gibbard, 2015). Core BN05 provides a record of sediment deposition in the Canada Basin, and thus glacial inputs into the western Arctic Ocean during most of the time interval to follow.

Considering the overall gradual growth of Pleistocene Arctic ice sheets, we infer that the shift from Siberian to North American sources between MIS 12 and 10 was primarily related to the expansion of the LIS, especially the northwestern Keewatin sector that discharges into the western Arctic Ocean. However, its further growth may have had an opposite effect due to a more massive ice sheet that required warmer climatic conditions and/or higher sea levels to destabilize it. Based on data for the last glacial cycle, the Keewatin sector of the LIS rested mostly on relatively 
elevated terrane of the Canadian Archipelago and adjacent mainland, fringed by a narrow continental shelf and dissected by numerous channels providing conduits for ice streams and evacuation of icebergs at rising sea levels (Stokes et al., 2005, 2009; England et al., 2009; Margold et al., 2015). The latter events are illustrated in BN05 data by intra-MIS 5 stadials with a consistent LIS signature (group 4: Fig. 7b). Especially high LIS scores characterize PW layers 2 and 3 attributed to MIS 5d and late MIS 3, respectively. A similar, LIS-dominated pattern likely represents the last deglaciation as indicated by a number of provenance studies (e.g., Stokes et al., 2005; Jang et al., 2013; Bazhenova et al., 2017).

In comparison to the LIS, a presumably much smaller ESIS, formed on a broad and overall flat East Siberian/Chukchi margin (Niessen et al., 2013; Dove et al., 2014; Colleoni et al., 2016), had to be responsive to sea-level changes even at low levels. It may be possible that the ESIS also increased in size by MIS 6, known as a time of a dramatic increase in glacial inputs from the Barents-Kara Ice Sheet into the eastern Arctic Ocean (e.g., O'Regan et al., 2008). A synchronous MIS 6 expansion of both North American and Siberian ice sheets and related ice shelves might explain the deep-keel glacial erosion of the Lomonosov Ridge at modern water depths exceeding $1000 \mathrm{~m}$ (Jakobsson et al., 2016, and references therein).

A concurrent interpretation can be proposed with a focus on sediment transportation processes as deposits of some glacial intervals, notably MIS 12 and parts of MIS 4 and 6, are associated with grain-size mode 2 , potentially indicating glacial debris flow/turbidite emplacement. Large debris flows entering the Chukchi Basin and continuing as turbidites into Canada Basin, as exemplified by sub-bottom sonar profiles (Niessen et al., 2013; Dove et al., 2014), may have overprinted deposition from icebergs. We note that deposits of MIS 4 and 6 also contain intervals where Siberian provenance is combined with interglacial positive scores (group 1: Fig. $7 b$ ) due to their fine-grained composition along with high illite content. These sediments likely represent deposition from suspension plumes, potentially marking especially strong deglacial meltwater discharge. A prominent fine-grained, finely laminated interval within MIS 4 deglaciation (possibly extending into MIS 3 ) has been reported from multiple cores across the Chukchi Basin-Mendeleev Ridge area (Adler et al., 2009; Matthiessen et al., 2010; Wang et al., 2013; Bazhenova et al., 2017).

Under modern conditions the BN05 site is mostly controlled by the Beaufort Gyre current circulation system, although it can also be affected by the Transpolar Drift during strong shifts in the Arctic Oscillation (Rigor et al., 2002). This setting probably applies to the Holocene and comparable interglacial conditions (Darby and Bischof, 2004). Some authors have suggested that during glacial periods the surface circulation that controls pathways of iceberg and sea-ice drift may have been considerably different from the modern pattern, with both North American and Siberian sources short- cutting the Arctic Ocean towards the Fram Strait (Bischof and Darby, 1997; Stärz et al., 2012). These changes would have potentially affected the study area, possibly making it more exposed to the Siberian provenance than under present conditions. However, the existing reconstructions based on very limited records with only crude stratigraphic controls, need to be elaborated by spatially and stratigraphically more representative data constraining past circulation changes. In particular, glacial maxima may be elusive, especially in the western Arctic Ocean, due to extremely low sedimentation rates or a hiatus, as exemplified by the LGM (Polyak et al., 2009; Poirier et al., 2012).

An overall integration of potential controls on sediment deposition in the study area during major identified types of glacial environments are illustrated in Fig. 8. More studies are needed to discriminate between different controls, including proxy records providing higher resolution for target intervals as well as modeling experiments to test spatial and stratigraphic variability in such factors as iceberg and meltwater discharge and their ensuing distribution pathways.

\subsubsection{Interglacial environments}

The long-term trend in interglacial environments reflected in a shift from negative to increasingly positive scores of interglacial proxies (group 1: Fig. 7b), with a threshold around the bottom of MIS 7, can be partially explained by the absence of calcareous foraminifers in the lower part of the record. However, even MIS 11, which has abundant foraminifers, has low interglacial scores, suggesting more controls. One possibility is that this trend was related to the evolution of circumArctic ice sheets that would have inevitably incurred changes in oceanic conditions, such as circulation and sea ice. An expansion of perennial sea ice in the western Arctic Ocean near the MIS 7 bottom has been proposed based on foraminiferal assemblages (Polyak et al., 2013; Lazar and Polyak, 2016). This step change has been tentatively attributed to the LIS growth that may have affected sea-ice conditions via increased albedo and/or higher meltwater inputs. This inference is consistent with a coeval change from mostly Siberian (group 3) to North American (group 4) provenance during interglacials in BN05 (Fig. 7b). In addition to a more lingering LIS during interstadials/interglacials, this shift in provenance could be related to a strengthening of the Beaufort Gyre as more sea ice filled the western Arctic Ocean.

More limited sea-ice cover in the older part of the middle Pleistocene could have also enhanced the production of dense brines at the Siberian margin, resulting in a deeper convection and cascading of shelf sediments to the deep basin. This scenario would explain an unusual grain-size composition of sediments in the older interglacials combining mode 2, indicative of winnowed silt, with a typical interglacial fine-grained mode 1 . 


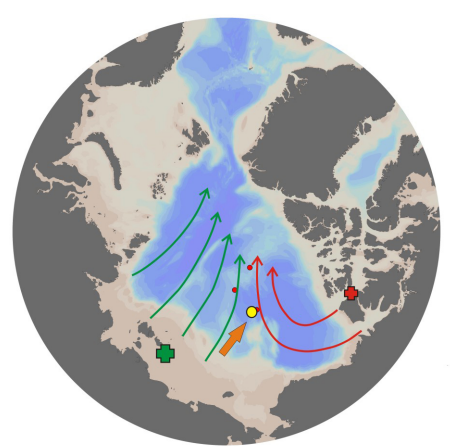

(a)

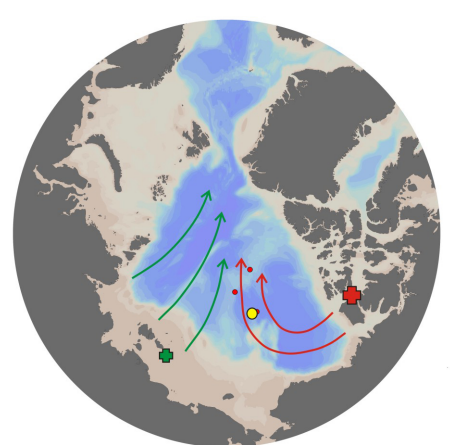

(b)

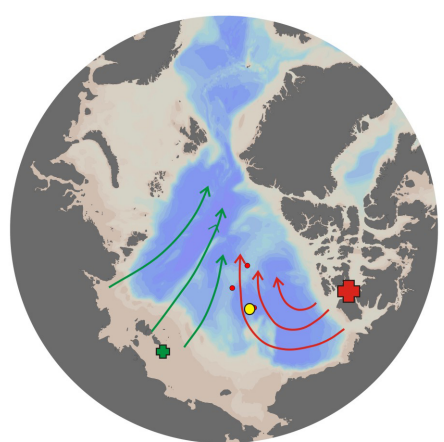

(c)

Figure 8. Schematic reconstruction of glacial environments in the western Arctic Ocean and factors controlling sedimentation at the BN05 site (yellow circle): surface circulation (red and green arrows), glacioturbidites (orange filled arrow), and relative ice-sheet size (red and green crosses). See Fig. 1 for modern circulation. (a) High ESIS inputs: MIS 4, 6, 12, and 14; (b) high LIS inputs: MIS 8 and 10; (c) especially high LIS inputs: intra-MIS 5 and 3.

\section{Summary and conclusions}

Sediment core ARC4-BN05 was collected from the Canada Basin in the vicinity of the Chukchi Plateau and the Mendeleev Ridge, Arctic Ocean, on the fourth Chinese National Arctic Research Expedition (CHINARE-IV). Based on correlation to earlier proposed Arctic Ocean stratigraphies (e.g., Adler et al., 2009; Stein et al., 2010a; Polyak et al., 2013) and $\mathrm{AMS}^{14} \mathrm{C}$ dating of the youngest sediments, the BN05 record covers the late to middle Quaternary (MIS 115 , ca. $0.5-0.6 \mathrm{Ma})$. The core was investigated for multiple sedimentary proxies including clay and bulk mineralogy, grain size, paleomagnetism, elemental content, and planktonic foraminiferal numbers with an average estimated age resolution of $4-5 \mathrm{ka}$ per sample. This study, facilitated by principal component analysis of major paleoceanographic variables, provides important new information about sedimentary environments and provenance in the western Arctic Ocean on glacial timescales. The results enhance our knowledge on the history of Arctic glaciations and interglacial conditions.

Glacially derived sediment can be discriminated between the North American and Siberian provenance by their mineralogical and textural signature. In particular, peaks of dolomite debris, including large dropstones, track the Laurentide Ice Sheet (LIS) discharge events, while the East Siberian Ice Sheet (ESIS) inputs are inferred from combined peaks of smectite, kaolinite, and chlorite associated with coarse sediment. Siberian provenance is also identified from high content of pyroxene, feldspar, and plagioclase, unrelated to coarse sediment. This sedimentary signature is interpreted to indicate sea-ice transport from the Siberian margin during interglacial/deglacial intervals. Full interglacial environments are characterized by overall fine grain size, high content of Mn (and resulting dark-brown sediment color), and elevated contents of calcite and chlorite. Foraminiferal tests are abundant in interglacial units in the upper part of the record
(MIS 1-7) and estimated MIS 11 but have very low numbers in other interglacials older than MIS 7, apparently due to dissolution.

In addition to glacial-interglacial cyclicity, the investigated record indicates variable impacts of LIS vs. ESIS on sediment inputs at different glacial events, along with a longterm change in middle to late Quaternary sedimentary environments. Based on the age model employed, major LIS inputs to the study area occurred during MIS 3, intra-MIS 5 and 7 events, MIS 8, and MIS 10, while ESIS signature is characteristic for MIS 4, MIS 6 and MIS 12. These differences may be related to ice-sheet configurations at different sea levels, sediment delivery mechanisms (iceberg rafting, suspension plumes, and debris flows), and surface circulation. A long-term shift in the pattern of sediment inputs shows an apparent step change near the estimated MIS 7/8 boundary (ca. $0.25 \mathrm{Ma}$ ), consistent with more sea-ice growth in the Arctic Ocean inferred from benthic foraminiferal assemblages (Lazar and Polyak, 2016). This development of Arctic Ocean paleoenvironments possibly indicates an overall glacial expansion at the western Arctic margins, especially in North America. Such expansion may have affected not only glacial but also interglacial conditions via increased albedo and/or higher meltwater inputs, as well as a strengthening of the Beaufort Gyre circulation as more sea ice filled the western Arctic Ocean.

Data availability. No data sets were used in this article.

\section{The Supplement related to this article is available online at doi:10.5194/cp-13-511-2017-supplement.}

Competing interests. The authors declare that they have no conflict of interest. 
Acknowledgements. We are grateful to the team of the 4th Chinese Arctic Research Expedition for their assistance with sample collection. Special thanks to Shijuan Yan for help with sampling and to Quanshu Yan for help in paper editing. This work was jointly supported by the Research Foundation of the First Institute of Oceanography, State Oceanic Administration of China (no. 2013G07, 2014G30), the Chinese Polar Environment Comprehensive Investigation \& Assessment Programmes (no. CHINARE 2017-03-02), and the National Natural Science Foundation of China (no. 41306205, 41676053, 40176136). Leonid Polyak's participation was supported by the US National Science Foundation award ARC-1304755. Comments from two anonymous reviewers helped improving the manuscript.

Edited by: T. Cronin

Reviewed by: two anonymous referees

\section{References}

Adler, R. E., Polyak, L., Ortiz, J. D., Kaufman, D. S., Channell, J. E. T., Xuan, C., Grottoli, A. G., Sellén, E., and Crawford, K. A.: Sediment record from the western Arctic Ocean with an improved Late Quaternary age resolution: HOTRAX core HLY0503-8JPC, Mendeleev Ridge, Global Planet. Change, 68, 18-29, 2009.

Andrews, J. T.: Icebergs and iceberg rafted detritus (IRD) in the North Atlantic: Facts and assumptions, Oceanography, 13, 100108, 2000.

Basilyan, A. E., Nikol'skyi, P. A., Maksimov, F. E., and Kuznetsov, V. Y.: Age of Cover Glaciation of the New Siberian Islands Based on ${ }^{230} \mathrm{Th} / \mathrm{U}$-dating of Mollusk Shells, Structure and Development of the Lithosphere, Paulsen, Moscow, 506-514, 2010.

Bazhenova, E., Fagel, N., and Stein, R.: North American origin of "pink-white" layers at the Mendeleev Ridge (Arctic Ocean): New insights from lead and neodymium isotope composition of detrital sediment component, Mar. Geol., 386, 44-55, 2017.

Behrends, M.: Reconstruction of sea-ice drift and terrigenous sediment supply in the Late Quaternary: heavy-mineral associations in sediments of the Laptev-Sea continental margin and the central Arctic Ocean, Rep. Polar Res., 310, 1-167, 1999.

Beuselinck, L., Govers, G., Poesen, J., Degraer, G., and Froyen, L.: Grain-size analysis by laser diffractometry: comparison with the sieve-pipette method, Catena, 32, 193-208, 1998.

Biscaye, P. F.: Distinction between kaolinite and chlorite in recent sediments by X-ray diffraction, Am. Mineral., 49, 1281-1289, 1964.

Biscaye, P. F.: Mineralogy and sedimentation of recent deep-sea clay in the Atlantic Ocean and adjacent seas and oceans, Geol. Soc. Am. Bull., 76, 803-832, 1965.

Bischof, J. F. and Darby, D. A.: Mid-to Late Pleistocene ice drift in the Western Arctic Ocean: evidence for a different circulation in the past, Science, 277, 74-78, 1997.

Bischof, J. F., Clark, D. L., and Vincent, J. S.: Origin of icerafted debris: Pleistocene paleoceanography in the western Arctic Ocean, Paleoceanography, 11, 743-756, 1996.

Blott, S. J. and Pye, K.: Particle size scales and classification of sediment types based on particle size distributions: review and recommended procedures, Sedimentology, 59, 2071-2096, 2012.
Chamley, H.: Clay Sedimentology, Springer, Berlin, 623 pp., 1989.

Clark, D. L., Whitman, R. R., Morgan, K. A., and Mackey, S. D.: Stratigraphy and glacialmarine sediments of the Amerasian Basin, central Arctic Ocean, Special Paper 181, Geological Society of America, The Geological Society of America, INC. 3300, Penrose Palce, P.O. Box 9140 Boulder, Colorado 80301, 57 pp., 1980.

Clark, D. L. and Hanson, A.: Central Arctic Ocean sediment texture: a key to ice transport mechanisms, in: Glacial-Marine Sedimentation, edited by: Molnia, B. F., Plenum Press, New York, 301-330, 1983.

Clark, D. L., Chern, L. A., Hogler, J. A., Mennicke, C. M., and Atkins, E. D.: Late Neogene climate evolution of the central Arctic Ocean, Mar. Geol., 93, 69-94, 1990.

Colleoni, F., Kirchner, N., Niessen, F., Quiquet, A., and Liakka, J.: An East Siberian ice shelf during the Late Pleistocene glaciations: Numerical reconstructions, Quaternary Sci. Rev., 147, 148-163, 2016.

Cook, H. E., Johnson, P. D., Matti, J. C., and Zemmels, I.: Methods of sample preparation and X-ray diffraction data analysis, X-ray mineralogy laboratory, edited by: Kaneps, A. G., Init Repts, DSDP XXVIII, 999-1007, http://www.deepseadrilling. org/28/volume/dsdp28_appendixIV.pdf, 1975.

Coulthard, R. D., Furze, M. F. A., Pienkowski, A. J., Nixon, F. C., and England, J. H.: New marine $\Delta \mathrm{R}$ values for Arctic Canada, Quatern. Geochronol., 5, 419-434, 2010.

Cronin, T. M., Polyak, L., Reed, D., Kandiano, E. S., Marzen, R. E., and Council, E. A.: A 600-ka Arctic sea-ice record from Mendeleev Ridge based on ostracodes, Quaternary Sci. Rev., 79, 157-167, 2013.

Cronin, T. M., DeNinno, L. H., Polyak, L., Caverly, E. K., Poore, R. Z., Brenner, A., Rodriguez-Lazaro, J., and Marzen, R. E.: Quaternary ostracode and foraminiferal biostratigraphy and paleoceanography in the western Arctic Ocean, Mar. Micropaleontol. 111, 118-133, doi:10.1016/j.marmicro.2014.05.001, 2014.

Dalrymple, R. W. and Maass, O. C.: Clay mineralogy of late Cenozoic sediments in the CESAR cores, Alpha Ridge, central Arctic ocean, Can. J. Earth Sci., 24, 1562-1569, 1987.

Darby, D. A.: Kaolinite and other clay minerals in Arctic Ocean sediments, J. Sediment. Petrol., 45, 272-279, 1975.

Darby, D. A., Bischof, J. F., Spielhagen, R. F., Marshall, S. A., Herman, S. W.: Arctic ice export events and their potential impact on global climate during the Late Pleistocene, Paleoceanography, 17, 1025, doi:10.1029/2001PA000639, 2002.

Darby, D. A.: Sources of sediment found in sea ice from the western Arctic Ocean, new insights into processes of entrainment and drift patterns, J. Geophys. Res., 108, 3257, doi:10.1029/2002JC001350, 2003.

Darby, D. A. and Bischof, J. F.: A Holocene record of changing Arctic Ocean ice drift, analogous to the effects of the Arctic Oscillation, Paleoceanography, 19, PA1027, doi:10.1029/2003PA000961, 2004.

Darby, D. A., Polyak, L., and Bauch, H. A.: Past glacial and interglacial conditions in the Arctic Ocean and marginal seas - a review, Prog. Oceanogr., 71, 129-144, 2006.

Darby, D. A., Ortiz, J., Polyak, L., Lund, S., Jakobsson, M., and Woodgate, R. A.: The role of currents and sea ice in both slowly deposited central Arctic and rapidly deposited Chukchi-Alaskan margin sediments, Global Planet. Change, 68, 58-72, 2009. 
Darby, D. A., Myers, W., Jakobsson, M., and Rigor, I.: Modern dirty sea ice characteristics and sources: The role of anchor ice, J. Geophys. Res., 116, C09008, doi:10.1029/2010JC006675, 2011.

Darby, D. A., Ortiz, J., Grosch, C., and Lund, S.: 1,500-year cycle in the Arctic Oscillation identified in Holocene Arctic sea-ice drift, Nat. Geosci., 5, 897-900, 2012.

Dethleff, D., Rachold, V., Tintelnot, T., and Antonow, M.: Sea-ice transport of riverine particles from the Laptev Sea to Fram Strait based on clay mineral studies, Int. J. Earth Sci., 89, 496-502, 2000.

Dethleff, D.: Entrainment and export of Laptev Sea ice sediments, Siberian Arctic, J. Geophys. Res.-Oceans, 110, C07009, doi:10.1029/2004JC002740, 2005.

Dong, L., Shi, X., Liu, Y., Fang, X., Chen, Z., Wang, C., Zou, J., and Huang, Y.: Mineralogical study of surface sediments in the western Arctic Ocean and their implications for material sources, Adv. Polar Sci., 25, 192-203, 2014.

Dove, D., Polyak, L., and Coakley, B.: Widespread, multi-source glacial erosion on the Chukchi margin, Arctic Ocean, Quaternary Sci. Rev., 92, 112-122, 2014

Dowdeswell, J. A., Villinger, H., Whittington, R. J., and Marienfeld, P.: Iceberg scouring in Scores by Sund and on the East Greenland continental shelf, Mar. Geol., 111, 37-53, 1993.

Dyke, A. S., Andrews, J. T., Clark, P. U., England, J. H., Miller, G. H., Shaw, J., and Veillette, J. J.: The Laurentide and Innuitian ice sheets during the Last Glacial Maximum, Quaternary Sci. Rev., 21, 9-31, 2002.

England, J. H., Furze, M. F. A., and Doupé, J. P.: Revision of the NW Laurentide Ice Sheet: implications for paleoclimate, the northeast extremity of Beringia, and Arctic Ocean sedimentation, Quaternary Sci. Rev., 28, 1573-1596, 2009.

Fagel, N., Not, C., Gueibe, J., Mattielli, N., and Bazhenova, E.: Late Quaternary evolution of sediment provenances in the Central Arctic Ocean: mineral assemblage, trace element composition and $\mathrm{Nd}$ and $\mathrm{Pb}$ isotope fingerprints of detrital fraction from the Northern Mendeleev Ridge, Quaternary Sci. Rev., 92, 140154, 2014.

Grosswald, M. G.: An ice sheet on the East Siberian shelf in the late Pleistocene, in: The Pleistocene of Siberia. Stratigraphy and interregional correlations, Novosibirsk, Nauka, Sibirskoye otdeleniye, 48-57, 1989.

Grosswald, M. G. and Hughes, T. J.: The Russian component of an Arctic Ice Sheet during the Last Glacial Maximum, Quaternary Sci. Rev., 21, 121-146, 2002

Haley, B. A. and Polyak, L.: Pre-modern Arctic Ocean circulation from surface sediment neodymium isotopes, Geophys. Res. Lett., 40, 1-5, 2013.

Hanslik, D., Jakobsson, M., Backman, J., Björck, S., Sellén, E., O'Regan, M., Fornaciari, E., and Skog, G.: Quaternary Arctic Ocean sea ice variations and radiocarbon reservoir age corrections, Quaternary Sci. Rev., 29, 3430-3441, 2010.

Harrison, J.C., St-Onge, M.R., Petrov, O., Strelnikov, S., Lopatin, B., Wilson, F., Tella, S., Paul, D., Lynds, T., Shokalsky, S., Hults, C., Bergman, S., Jepsen, H. F., and Solli, A.: Geological Map of the Arctic, Open File, Geol. Survey Canada, p. 5816, 2008.

Head, M. J. and Gibbard, P. L.: Early-Middle Pleistocene transitions: linking terrestrial and marine realms, Quatern. Int., 389, 7-46, 2015.
Hebbeln, D.: Flux of ice-rafted detritus from sea ice in the Fram Strait, Deep-Sea Res. Pt. II, 47, 1773-1790, 2000.

Hesse, R. and Khodabakhsh, S.: Anatomy of Labrador Sea Heinrich layers, Mar. Geol., 380, 44-66, 2016.

Hughes, T. J., Denton, G. H., and Grosswald, M. G.: Was there a late-Würm Arctic ice sheet?, Nature, 266, 596-602, 1977.

Ivanova, V. V.: Geochemicalfeatures of formation of massive ground ice bodies (New Siberian Island, Siberian Arctic) as the evidence of their genesis, Earth's Cryosphere, 16, 56-70, 2012.

Jakobsson, M., Løvlie, R., Al-Hanbali, H., Arnold, E., Backman, J., and Mörth, M.: Manganese and color cycle in Arctic Ocean sediments constrain Pleistocene chronology, Geology, 28, 23-26, 2000.

Jakobsson, M., Polyak, L., Edwards, M., Kleman, J., and Coakley, B.: Glacial geomorphology of the Central Arctic Ocean: the Chukchi Borderland and the Lomonosov Ridge, Earth Surf. Proc. Land., 33, 526-545, 2008.

Jakobsson, M., Andreassen, K., Bjarnadóttir, L. R., Dove, D., Dowdeswell, J. A., England, J. H., Funder, S., Hogan, K., Ingólfsson,Ó., Jennings, A., Larsen, N, K., Kirchner, N., Landvik, J. Y., Mayer, L., Mikkelsen, N., Möller, P., Niessen, F., Nilsson, J., O'Regan, M., Polyak, L., Nørgaard-Pedersen, N., and Stein, R.: Arctic Ocean glacial history, Quaternary Sci. Rev., 92, 40-67, 2014.

Jakobsson, M., Nilsson, J., Anderson, L., Backman, J., Björk, G., Cronin, T. M., Kirchner, N., Koshurnikov, A., Mayer, L., Noormets, R., O’Regan, M., Stranne, C., Ananiev, R., Macho, N. B., Cherniykh, D., Coxall, H., Eriksson, B., Flodén, T., Gemery, L., Gustafsson, O., Jerram, K., Johansson, C., Khortov, A., Mohammad, R., and Semiletov, I.: Evidence for an ice shelf covering the central Arctic Ocean during the penultimate glaciation, Nat. Commun., 1-10, doi:10.1038/ncomms10365, 2016.

Jang, K., Han, Y., Huh, Y., Nam, S., Stein, R., Mackensen, A., and Matthiessen, J.: Glacial freshwater discharge events recorded by authigenic neodymium isotopes in sediments from the Mendeleev Ridge, western Arctic Ocean, Earth Planet. Sc. Lett., 369-370, 148-157, 2013.

Junttila, J.: Clay minerals in response to Mid-Pliocene glacial history and climate in the polar regions (ODP, Site 1165, Prydz Bay, Antarctica and Site 911, Yermak Plateau, Arctic Ocean), Acta Universitat Ouluensis, A 481, 48 pp., 2007.

Kalinenko, V. V.: Clay minerals in sediments of the Arctic Seas, Lithol. Mineral Resour., 36, 362-372, 2001.

Kaparulina, E., Strand, K., and Lunkka, J. P.: Provenance analysis of central Arctic Ocean sediments: Implications for circumArctic ice sheet dynamics and ocean circulation during Late Pleistocene, Quaternary Sci. Rev., 147, 210-220, 2016.

Keigwin, L. D., Donnelly, J. P., Cook, M. S., Driscoll, N. W., and Brigham-Grette, J.: Rapid sea-level rise and Holocene climate in the Chukchi Sea, Geology, 34, 861-864, doi:10.1130/G22712.1, 2006.

Kim, B. I. and Slobodin, V. Y.: Main stages of the evolution of East Arctic shelves of Russia and Canadian Arctic in the Paleogene and Neogene, in: Geologiya skladchatogo obramleniya Ameraziiskogo subbasseina (Geology of the Folded Framing of the Amerasian Subbasin), Sevmorgeologiya, 1St. Petersburg, 04-116, 1991. 
Knies, J. and Vogt, C.: Freshwater pulses in the eastern Arctic Ocean during Saalian and early Weichselian ice-sheet collapse, Quatern. Res., 60, 243-251, 2003.

Knies, J., Kleiber, H. P., Matthiessen, J., Müller, C., and Nowaczyk, N.: Marine ice-rafted debris records constrain maximum extent of Saalian and Weichselian ice-sheets along the northern Eurasian margin, Global Planet. Change, 31, 45-64, 2001.

Kobayashi, D., Yamamoto, M., TIrino, T., Nam, S.-I., Park, Y.-H., Harada, N., Nagashima, K., Chikita, K., a nd Saitoh, S. I.: Distribution of detrital minerals and sediment color in western Arctic Ocean and northern Bering Sea sediments: changes in the provenance of western Arctic Ocean sediments since the last glacial period, Polar Science, 10, 519-531, 2016.

Krylov, A. A., Andreeva, I. A., Vogt, C., Backman, J., Krupskaya, V. V., Grikurov, G. E., Moran, K., and Shoji, H.: A shift in heavy and clay mineral provenance indicates a middle Miocene onset of a perennial sea ice cover in the Arctic Ocean, Paleoceanography, 23, PA1S06, doi:10.1029/2007PA001497, 2008.

Krylov, A. A., Stein, R., and Ermakova, L. A.: Clay minerals as indicators of late quaternary sedimentation constraints in the Mendeleev Rise, Amerasian Basin, Arctic Ocean, Lithol. Mineral Resour., 49, 103-116, 2014.

Larsen, E., Kjær, K. H., Demidov, I. N., Funder, S., Grøsfjeld, K., Houmark-Nielsen, M.,Jensen, M., Linge, H., and Lyså, A.: Late Pleistocene glacial and lake history of northwestern Russia, Boreas, 35, 394-424, 2006.

Lazar, K. B. and Polyak, L.: Pleistocene benthic foraminifers in the Arctic Ocean: Implications for seaice and circulation history, Mar Micropaleontol, 126, 19-30, 2016.

Löwemark, L., Jakobsson, M., Mörth, M., and Backman, J.: Arctic Ocean Mn contents and sediment colour cycles, Polar Res., 27, 105-113, 2008.

Löwemark, L., März, C., O’Regan, M., and Gyllencreutz, R. Arctic Ocean Mn-stratigraphy: genesis, synthesis and inter-basin correlation, Quaternary Sci. Rev., 92, 97-111, 2014.

Margold, M., Stokes, C. R., and Clark, C. D.: Ice streams in the Laurentide Ice Sheet: Identification, characteristics and comparison to modern ice sheets, Earth-Sci. Rev., 143, 117-146, 2015.

März, C., Stratmann, A., Matthiessen, J., Meinhardt, A., Eckert, S., Schnetger, B., Vogt, C., Stein, R., and Brumsack, H.: Manganeserich brown layers in Arctic Ocean sediments: composition, formation mechanisms, and diagenetic overprint, Geochim. Cosmochim. Acta, 75, 7668-7687, 2011.

MathWorks: MATLAB, Statistical Package, MathWorks, 2014.

Matthiessen, J., Niessen, F., Stein, R., and Naafs, B. D.: Pleistocene Glacial Marine Sedimentary Environments at the Eastern Mendeleev Ridge, Arctic Ocean, Polarforschung, 79, 123-137, 2010.

Naidu, A. S., Burrell, D. C., and Hood, D. W.: Clay mineral composition and geological significance of some Beaufort Sea sediments, J. Sediment. Petrol., 41, 691-694, 1971.

Naidu, A. S., Creager, J. S., and Mowatt, T. C.: Clay mineral dispersal patterns in the north Bering and Chukchi Seas, Mar. Geol., 47, 1-15, 1982.

Niessen, F., Hong, J. K., Hegewald, A., Matthiessen, J., Stein, R., Kim, H., Kim, S., Jensen, L., Jokat, W., Nam, S.-I., and Kang, S.-H.: Repeated Pleistocene glaciation of the East Siberian Continental Margin, Nat. Geosci., 6, 842-846, 2013.
Nürnberg, D., Wollenburg, I., Dethleff, D., Eicken, H., Kassens, H., Letzig, T., Reimnitz, E., and Thiede, J.: Sediments in Arctic sea ice: Implications for entrainment, transport and release, Mar. Geol., 119, 185-214, 1994.

Nwaodua, E. C., Ortiz, J. D., and Griffith, E. M.: Diffuse spectral reflectance of surficial sediments indicates sedimentary environments on the shelves of the Bering Sea and western Arctic, Mar. Geol., 355, 218-233, 2014.

Okulitch, A. V. (compiler): Geology of the Canadian Archipelago and North Greenland, in: Innuitian orogen and Arctic Platform: Canada and Greenland, $1: 200000$, edited by: Trettiln, H. P., The Geology of North America, The Geological Society of America, Boulder, Colorado, 1991.

O’Regan, M., King, J., Backman, J., Jakobsson, M., Pälike, H., Moran, K., Heil, C., Sakamoto, T., Cronin, T. M., and Jordan, R. W.: Constraints on the Pleistocene chronology of sediments from the Lomonosov Ridge, Paleoceanography, 23, PA1S19, doi:10.1029/2007PA001551, 2008.

Ortiz, J. D., Polyak, L., Grebmeier, J. M., Darby, D., Eberl, D. D., Naidu, S., and Nof, D.: Provenance of Holocene sediment on the Chukchi-Alaskan margin based on combined diffuse spectral reflectance and quantitative X-Ray diffraction analysis, Global Planet. Change, 68, 73-84, 2009.

Pelto, B. M.: Sedimentological, geochemical and isotopic evidence for the establishment of modern circulation through the Bering Strait and depositional environment history of the Bering and Chukchi seas during the last deglaciation, Paper 108, Ms Thesis, University of Massachusetts, Amherst, $134 \mathrm{pp}$, http://scholarworks.umass.edu/cgi/viewcontent.cgi?article= 1078\&context=masters_theses_2, 2014.

Phillips, R. L. and Grantz, A.: Regional variations in provenance and abundance of ice-rafted clasts in Arctic Ocean sediments: Implications for the configuration of late Quaternary oceanic and atmospheric circulation in the Arctic, Mar. Geol., 172, 91-115, 2001.

Poirier, R. K., Cronin, T. M., Briggs Jr., W. M., and Lockwood, R.: Central Arctic paleoceanography for the last $50 \mathrm{kyr}$ based on ostracode faunal assemblages, Mar. Micropaleontol., 88-89, 6576, 2012.

Polyak, L., Edwards, M. H., Coakley, B. J., and Jakobsson, M.: Ice shelves in the Pleistocene Arctic Ocean inferred from glaciogenic deep-sea bedforms, Nature, 410, 453-459, 2001.

Polyak, L., Curry, W. B., Darby, D. A., Bischof, J., and Cronin, T. M.: Contrasting glacial/interglacial regimes in the Western Arctic Ocean as exemplied by a sedimentary record from the Mendeleev Ridge, Palaeogeogr. Palaeocl., 203, 73-93, 2004.

Polyak, L., Darby, D. A., Bischof, J., and Jakobsson, M.: Stratigraphic constraints on late Pleistocene glacial erosion and deglaciation of the Chukchi margin, Arctic Ocean, Quatern. Res., 67, 234-245, doi:10.1016/j.yqres.2006.08.001, 2007.

Polyak, L., Bischof, J., Ortiz, J. D., Darby, D. A., Channell, J. E. T., Xuan, C., Kaufman, D. S., Lovlie, R., Schneider, D. A., Eberl, D. D., Adler, R. E., and Council, E. A.: Late Quaternary stratigraphy and sedimentation patterns in the western Arctic Ocean, Global Planet. Change, 68, 5-17, 2009.

Polyak, L., Alley, R. B., Andrews, J. T., Brigham-Grette, J., Cronin, T. M., Darby, D. A., Dyke, A. S., Fitzpatrick, J. J., Funder, S., Holland, M., Jennings, A. E., Miller, G. H., O’Regan, M., Savelle, J., Serreze, M., St. John, K., White, J. W. C., and Wolff, 
E.: History of sea ice in the Arctic, Quaternary Sci. Rev., 29, 1757-1778, 2010.

Polyak, L., Best, K. M., Crawford, K. A., Council, E. A., and StOnge, G.: Quaternary history of sea ice in the western Arctic Ocean based on foraminifera, Quaternary Sci. Rev., 79, 145-156, 2013.

Ramaswamy, V. and Rao, P. S.: Grain Size Analysis of Sediments from the Northern Andaman Sea: Comparison of Laser Diffraction and Sieve-Pipette Techniques, J. Coast. Res., 22, 10001009, 2006.

Rigor, I. G., Wallace, J. M., and Colony, R. L.: Response of sea ice to the Arctic Oscillation, J. Climate, 15, 2648-2663, 2002.

Rudels, B.: Arctic Ocean circulation, in: Encyclopedia of Ocean Sciences, edited by: Steele, J. H., Turekian, K. K., and Thorpe, S. A., Elsevier, Amsterdam, Elsevier Science Direct, 211-225, 2009.

Schoster, F., Behrends, M., Müller, C., Stein, R., and Wahsner, M.: Modern river discharge in the Eurasian Arctic Ocean: Evidence from mineral assemblages and major and minor element distributions, Int. J. Earth Sci., 89, 486-495, 2000.

Sellén, E., O'Regan, M., and Jakobsson, M.: Spatial and temporal Arctic Ocean depositional regimes: a key to the evolution of ice drift and current patterns, Quaternary Sci. Rev., 29, 3644-3664, 2010.

Sharma, M., Basu, A. R., and Nesterenko, G. V.: Temporal Sr-, Ndand $\mathrm{Pb}$ isotopic variations in the Siberian flood basalts: implications for the plume-source characteristics, Earth Planet. Sc. Lett., 113, 365-381, 1992.

Simon, Q., Hillaire-Marcel, C., St-Onge, G., and Andrews, J.: North-eastern Laurentide, western Greenland and southern Innuitian ice stream dynamics during the last glacial cycle, J. Quaternary Sci., 29, 14-26, 2014.

Slobodin, V. Y., Kim, B. I., Stepanova, G. V., and Kovalenko, F. Y.: Differentiation of the Aion borehole section based on the biostratigraphic data, in: Stratigrafiya i paleontologiya mezokainozoya Sovetskoi Arktiki (Stratigraphy and Paleontology of the Meso-Cenozoic in the Soviet Arctic), Sevmorgeologiya, Leningrad, 43-58, 1990.

Spielhagen, R. F., Bonani, G., Eisenhauer, A., Frank, M., Frederichs, T., Kassens, H., Kubik, P. W., Mangini, A., NörgaardPedersen, N., Nowaczyk, N. R., Schäper, S., Stein, R., Thiede, J., Tiedemann, R., Wahsner, M.: Arctic Ocean evidence for Late Quaternary initiation of northern Eurasian ice sheets, Geology, 25, 783-786, 1997.

Spielhagen, R. F., Baumann, K. H., Erlenkeuser, H., Nowaczyk, N. R., Nørgaard-Pedersen, N., Vogt, C., and Weiel, D.: Arctic Ocean deep-sea record of Northern Eurasian ice sheet history, Quaternary Sci. Rev., 23, 1455-1483, 2004.

Stärz, M., Gong, X., Stein, R., Darby, D. A., Kauker, F., and Lohmann, G.: Glacial shortcut of Arctic sea-ice transport, Earth Planet. Sc. Lett., 357-358, 257-267, 2012.

Stein, R., Grobe, H., and Wahsner, M.: Organic carbon, carbonate, and clay mineral distributions in eastern central Arctic Ocean surface sediments, Mar. Geol., 119, 269-285, 1994.

Stein, R.: Arctic Ocean Sediments: Processes, Proxies, and Paleoenvironment, Elsevier, Amsterdam, 1-592, 2008.

Stein, R., Matthiessen, J., and Niessen, F.: Re-Coring at Ice Island T3 Site of Key Core FL-224 (Nautilus Basin, Amerasian Arc- tic): Sediment Characteristics and Stratigraphic Framework, Polarforschung, 79, 81-96, 2010a.

Stein, R., Matthiessen, J., Niessen, F., Krylov, A., Nam, S., and Bazhenova, E.: Shipboard Geology Group.: Towards a better (litho-) stratigraphy and reconstruction of Quaternary paleoenvironment in the Amerasian Basin (Arctic Ocean), Polarforschung, 79, 97-121, 2010b.

Stein, R., Fahl, K., and Müller J.: Proxy Reconstruction of Cenozoic Arctic Ocean Sea-Ice History - from IRD to IP25, Polarforschung, 82, 37-71, 2012.

Stokes, C. R., Clark, C. D., Darby, D., and Hodgson, D. A.: Late Pleistocene ice export events into the Arctic Ocean from the M'Clure Strait Ice Stream, Canadian Arctic Archipelago, Global Planet. Change, 49, 139-162, 2005.

Stokes, C. R., Clark, C. D., and Storrar, R.: Major changes in ice stream dynamics during deglaciation of the north-western margin of the Laurentide Ice Sheet, Quaternary Sci. Rev., 28, 721-738, 2009.

Svendsen, J. I., Alexanderson, H., Astakhov, V. I., Demidov, I., Dowdeswell, J. A., Funder, S., Gataullin, V., Henriksen, M., Hjort, C., Houmark-Nielsen, M., Hubberten, H. W., Ingólfsson, O., Jakobsson, M., Kjær, K. H., Larsen, E., Lokrantz, H., Lunkka, J. P., Lyså, A., Mangerud, J., Matioushkov, A., Murray, A., Möller, P., Niessen, F., Nikolskaya, O., Polyak, L., Saarnisto, M., Siegert, R., Siegert, M. J., Spielhagen, R. F., and Stein, R. Late Quaternary ice sheet history of Northern Eurasia, Quaternary Sci. Rev., 23, 1229-1271, 2004.

Viscosi-Shirley, C., Mammone, K., Pisias, N., and Dymond, J.: Clay mineralogy and multi-element chemistry of surface sediments on the Siberian-Arctic shelf: Implications for sediment provenance and grain size sorting, Cont. Shelf Res., 23, 1175-1200, 2003.

Vogt, C.: Regional and temporal variations of mineral assemblages in Arctic Ocean sediments as climatic indicator during glacial/interglacial changes, Rep. Polar Mar. Res., 251, 1-309, 1997.

Vogt, C. and Knies, J.: Sediment dynamics in the Eurasian Arctic Ocean during the last deglaciation - The clay mineral group smectite perspective, Mar. Geol., 250, 211-222, 2008.

Vogt, C. and Knies, J.: Sediment pathways in the western Barents Sea inferred from clay mineral assemblages in surface sediments, Norweg. J. Geol., 89, 41-55, 2009.

Vogt, C., Knies, J., Spielhagen, R. F., and Stein, R.: Detailed mineralogical evidence for two nearly identical glacial/deglacial cycles and Atlantic water advection to the Arctic Ocean during the last 90,000 years, Global Planet. Change, 31, 23-44, 2001.

Wahsner, M., Müller, C., Stein, R., Ivanov, G., Levitan, M., Shelekova, E., and Tarasov, G.: Clay mineral distributions in surface sediments from the Central Arctic Ocean and the Eurasian continental margin as indicator for source areas and transport pathways: a synthesis, Boreas, 28, 215-233, 1999.

Wang, D. and Hesse, R.: Continental slope sedimentation adjacent to an ice-margin. II. Glaciomarine depositional facies on Labrador Slope and glacial cycles, Mar. Geol., 135, 65-96, 1996.

Wang, R., Xiao, W., Li, W., and Sun, Y.: Late Quaternary ice-rafted detritus events in the Chukchi Basin, western Arctic Ocean, Chinese Sci. Bull., 55, 432-440, 2010.

Wang, R., Xiao, W., März, C., and Li, Q.: Late Quaternary paleoenvironmental changes revealed by multi-proxy records from 
the Chukchi Abyssal Plain, western Arctic Ocean, Global Planet. Change, 108, 100-118, 2013.

Winkler, A., Wolf-Welling, T. C. W., Stattegger, K., and Thiede, J.: Clay mineral sedimentation in high northern latitude deep-sea basins since the Middle Miocene (ODP Leg 151, NAAG), Int. J. Earth Sci., 91, 133-148, 2002.

Winter, B. L., Johnson, C. M., and Clark, D. L.: Strontium, neodymium, and lead isotope variations of authigenic and silicate sediment components from the Late Cenozoic Arctic Ocean: implications for sediment provenance and the source of trace metals in seawater, Geochim. Cosmochim. Ac., 61, 4181-4200, 1997.

Xiao, W., Wang, R., Polyak, L., Astakhov, A., and Cheng, X.: Stable oxygen and carbon isotopes in planktonic foraminifera Neogloboquadrina pachyderma in the Arctic Ocean: an overview of published and new surface-sediment data, Mar. Geol., 352, 397-408, 2014.
Xuan, C. and Channell, J. E. T.: Origin of apparent magnetic excursions in deep-sea sediments from Mendeleev-Alpha Ridge (Arctic Ocean), Geochem. Geophy. Geosy., 11, Q02003, doi:10.1029/2009GC002879, 2010.

Yurco, L. N., Ortiz, J. D., Polyak, L., Darby, D. A., and Crawford, K. A.: Clay mineral cycles identified by diffuse spectral reflectance in Quaternary sediments from the Northwind Ridge: implications for glacial-interglacial sedimentation patterns in the Arctic Ocean, Polar Res., 29, 176-197, 2010.

Zou, H.: An X-ray diffraction approach: bulk mineral assemblages as provenance indicator of sediments from the Arctic Ocean, $\mathrm{PhD}$ Thesis, University of Bremen, Bremen, 1-104, 2016. 